\title{
Tectonics of the West Antarctic Rift System: New Light on the History and Dynamics of Distributed Intracontinental Extension
}

\author{
C. S. Siddoway ${ }^{l}$
}

\begin{abstract}
The West Antarctic rift system (WARS) is the product of multiple stages of intracontinental deformation from Jurassic to Present. The Cretaceous rifting phase accomplished $>100$ percent extension across the Ross Sea and central West Antarctica, and is widely perceived as a product of pure shear extension orthogonal to the Transantarctic Mountains that led to breakup and opening of the Southern Ocean between West Antarctica and New Zealand. New structural, petrological, and geochronological data from Marie Byrd Land reveal aspects of the kinematics, thermal history, and chronology of the Cretaceous intracontinental extension phase that cannot be readily explained by a single progressive event. Elevated temperatures in "Lachlan-type" crust caused extensive crustal melting and mid-crustal flow within a dextral transcurrent strain environment, leading to rapid extension and locally to exhumation and rapid cooling of a migmatite dome and detachment footwall structures. Peak metamorphism and onset of crustal flow that brought about WARS extension between $105 \mathrm{Ma}$ and $90 \mathrm{Ma}$ is kinematically, temporally, and spatially linked to the active convergent margin system of East Gondwana. West Antarctica-New Zealand breakup is distinguished as a separate event at 83-70 Ma, from the standpoint of kinematics and thermal evolution.
\end{abstract}

\section{INTRODUCTION}

Heightened interest in West Antarctica (WANT) and the West Antarctic rift system (WARS) comes from new determinations of the mantle thermal profile (Lawrence et al., 2006)

${ }^{1}$ Department of Geology Colorado College, Colorado Springs, CO 80903, USA (csiddoway@coloradocollege.edu). and the context for active volcanism (Behrendt et al., 1994, 1996) arising at a time of instability of the West Antarctic ice sheet, when information is sought about the influence of underlying crustal structures on glaciological and glacialmarine systems (e.g., Holt et al., 2006; Lowe and Anderson, 2002; Vaughan et al., 2006). The question of heat flux arising from warm mantle beneath thinned crust is of obvious consequence for ice-sheet dynamics (Maule et al., 2005). The area of thin crust corresponding to the WARS (Figure 1) includes the Ross Sea and Ross Ice Shelf, the West Antarctic ice sheet (WAIS), and Marie Byrd Land (Behrendt et al., 1991; Storey et al., 1999; Fitzgerald, 2002; Siddoway et al., 2005).

In the geological record the WARS has distinctive but differing expressions in both Cenozoic and Mesozoic time. By far the better-known rift phase is the mid-Cenozoic to Present interval. Widespread basaltic volcanism (Behrendt et al., 1994, 1996; Finn et al., 2005; Rocchi et al., 2005), slow mantle seismic velocities (Danesi and Morelli, 2001; Ritzwoller et al., 2001; Sieminski et al., 2003), and anomalous elevation of thinned continental crust (LeMasurier and Landis, 1996; LeMasurier, 2008) are the hallmarks of the Cenozoic rift. The Victoria Land Basin and Terror rift, on the western limit of the WARS, record modest extension on the order of $150 \mathrm{~km}$ in Eocene-Oligocene time (Stock and Cande, 2002; Davey and DeSantis, 2006). The dramatic relief of the Transantarctic Mountains (TAM) developed in the Eocene (ten Brink et al., 1997; Fitzgerald, 2002), and voluminous basin sedimentation commenced (Hamilton et al., 1998; Cape Roberts Science Team, 2000; Luyendyk et al., 2001; Karner et al., 2005), considerably later than major extension in the WARS. Not surprising in light of the dominantly Eocene activation of the TAM boundary (ten Brink et al., 1997; Fitzgerald, 2002), onland structures attributable to preceding Cretaceous events are few in the TAM (Wilson, 1992). 


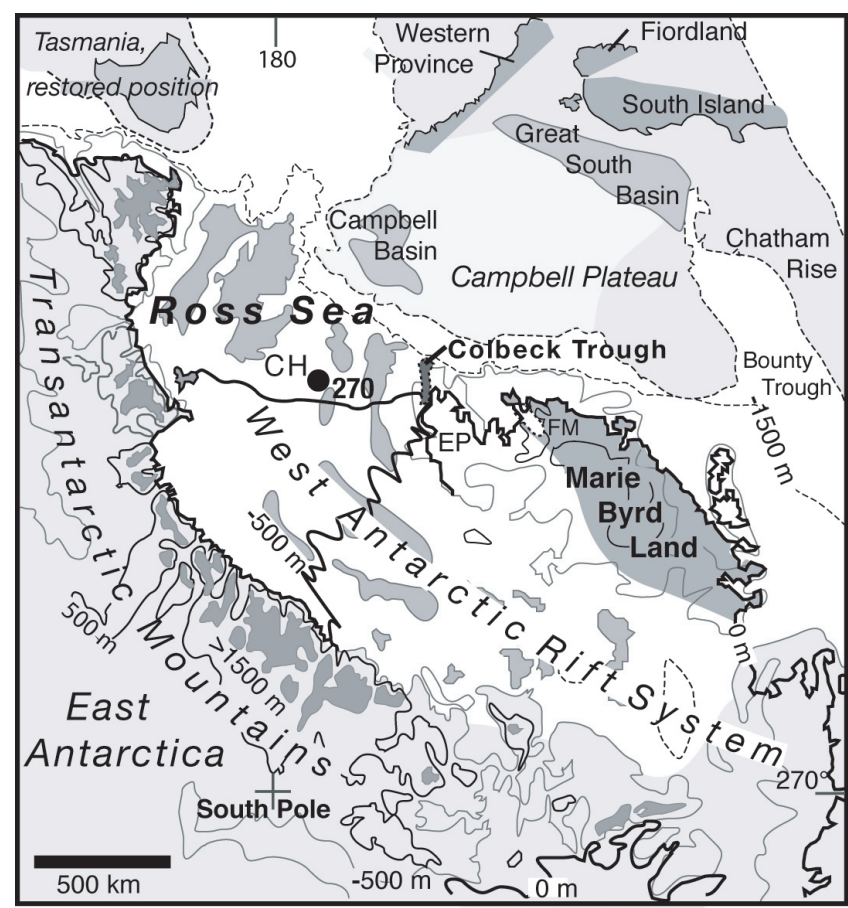

FIGURE 1 The Cretaceous West Antarctic rift system at ca. $90 \mathrm{Ma}$, illustrating the positions of Marie Byrd Land and New Zealand/Campbell Plateau along the East Gondwana margin. The rifted margin corresponds to the $-1500 \mathrm{~m}$ contours (dashed-line pattern). The tight fit of the reconstruction, the linear to curvilinear continental margin, and the pronounced depth increase suggest fault control and steep fault geometry. The diagram is based on the reconstructions of Lawver and Gahagan (1994) and Sutherland (1999). The present-day position of the Transantarctic Mountains, as labeled, corresponds to the western tectonic boundary of the West Antarctic Rift System. FM = Fosdick Mountains; EP = Edward VII Peninsula; $270=$ DSDP site 270 .

The lesser-known phase of extension and lithospheric thinning that brought about formation of the vast rift system $\left(\sim 1.2 \times 10^{6} \mathrm{~km}^{2}\right)$ did not occur in Cenozoic but in Mesozoic time (Tessensohn and Wörner, 1991; Lawver and Gahagan, 1994; Luyendyk, 1995). Although the origins of the WARS may be linked to Weddell Sea opening and Ferrar magmatism in the Jurassic (Grunow et al., 1991; Wilson, 1993; Jokat et al., 2003; Elliot and Fleming, 2004), dramatic intracontinental extension occurred in Cretaceous time. Much of the basis of knowledge about the Ross Sea sector of the rift comes from ocean bottom seismograph, multichannel seismic reflection, and gravity surveys that revealed a N-S structure of elongate basins marked by a positive gravity anomaly and high seismic velocities in the lower crust and 1-4 km of inferred Mesozoic sedimentary fill (Cooper and Davey, 1985; Cooper et al., 1997; Trey et al., 1997). Paradoxically, major sedimentary infilling of basins with material postdat- ing regional unconformity RU6 evidently was delayed until the Eocene to Miocene (Hamilton et al., 1998; Wilson et al., 1998; Cape Roberts Science Team, 2000; Luyendyk et al., 2001; Karner et al., 2005). This is despite the rapidity of the large magnitude extension, on the order of $600 \mathrm{~km}$ in the south, up to $>1000 \mathrm{~km}$ in the north achieved in as little as 20 m.y. (DiVenere et al., 1996; Luyendyk et al., 1996). A second paradox is that breakup between WANT and New Zealand (NZ) did not exploit rift structures but rather cut at a high angle across basement highs and basins of the Ross Sea (Tessensohn and Wörner, 1991; Lawver and Gahagan, 1994; Sutherland, 1999). Wrench deformation and the presence of strike slip transfer systems was postulated (Grindley and Davey, 1982) but not substantiated from exposures on land.

New perspective on intracontinental extension in the WARS comes from geological and geophysical research that investigates the exposed bedrock of WANT, NZ, and the Tasman Sea region (Figure 1). WANT, NZ, and submarine plateaus formed a contiguous segment of the convergent margin of East Gondwana in Early Cretaceous time, with arc magmatism recorded in Marie Byrd Land-NZ. Transtension-extension occurred in a back arc to inboard setting, forming the intracontinental West Antarctic rift system and Great South Basin-Campbell Plateau extensional province (Figure 1).

Since 1990, data acquired from geological investigations on land and from airborne and marine geophysical surveys in the region of Marie Byrd Land have dramatically increased the understanding of the eastern WARS, with consequences for our conception of the Cretaceous to Present multistage evolution of the West Antarctic rift system as a whole. The aim of this paper is to summarize the tectonic evolution of western Marie Byrd Land (MBL) (Figure 2) and of neighboring segments of the proto-Pacific margin of East Gondwana (Figure 3). Little affected by Cenozoic events (cf. Fitzgerald, 2002; Stock and Cande, 2002), the eastern Ross Sea region preserves a clear record of the kinematics, magmatism, and thermal history of the Early Cretaceous large-scale opening of the WARS.

Knowledge of the Cretaceous tectonic evolution of the WARS-NZ-Tasman Sea region provides an important foundation for contemporary research in WANT, including studies of the Cretaceous to present landscape evolution (LeMasurier and Landis, 1996; LeMasurier, 2008) involving a postulated orogenic plateau (Bialas et al., 2007; Huerta, 2007), the origins of the Southern Ocean's diffuse alkaline magmatism (Finn et al., 2005; Rocchi et al., 2005), the causes for Cenozoic structural reactivation (e.g., Salvini et al., 1997; Rossetti et al., 2003a,b) and seismicity (Winberry and Anandakrishnan, 2004), and the affects of inherited structures upon ice-bedrock interactions of the dynamic WAIS (Lowe and Anderson, 2002; Holt et al., 2006; Vaughan et al., 2006; Sorlien et al., 2007). 
Extent of the West Antarctic Rift System (WARS) and Character of WARS Crust

The region corresponding to the Cretaceous WARS includes the Ross Sea and Ross Ice Shelf, the area of the WAIS, and Marie Byrd Land (Behrendt, 1991, 1999; Behrendt et al., 1991; Cooper et al., 1991a,b; Storey et al., 1999; Trey et al., 1999). Measured orthogonal to the TAM, the WARS widens from $600 \mathrm{~km}$ in the south (Storey et al., 1999) to $1200 \mathrm{~km}$ across the northern Ross Sea (Luyendyk et al., 2003). Thickness of continental crust ranges from $17-19 \mathrm{~km}$ for the Central and Eastern Basins of the Ross Sea to 23-24 $\mathrm{km}$ beneath basement highs (Cooper et al., 1991b, 1997; Davey and Brancolini, 1995; Luyendyk et al., 2001). There is a similar range beneath central West Antarctica (Behrendt et al., 1994; Bell et al., 1998). The crust underlying western MBL is ca. $23 \mathrm{~km}$ thick, based on airborne geophysics (Figure 2) (Ferraccioli et al., 2002; Luyendyk et al., 2003). This provides evidence that the region of western MBL that is above sea level is part of the WARS province.

The western margin of the WARS extensional province coincides with the TAM, at the long-standing tectonic boundary of the East Antarctica (EANT) craton that initiated as a Neoproterozoic rift margin (Dalziel, 1997), underwent convergence during the Ross Orogeny (Stump, 1995), and was reactivated during the initial two-plate phase of Gondwana breakup in the Jurassic Era (Dalziel et al., 1987). Tholeiitic Ferrar magmatism (Elliot et al., 1999; Elliot and Fleming, 2004) and modest extension to transtension initiated in the WARS at this time (Storey, 1991, 1992; Wilson, 1993). The Cretaceous WARS has been inferred to be an asymmetrical extensional system with the TAM forming the structural upper plate and the WARS, the lower plate (e.g., Fitzgerald et al., 1986; Stern and ten Brink, 1989; Fitzgerald and Baldwin, 1997; compare Lister et al., 1991).

Beneath the Ross Sea, gravity and marine seismic data delineate a crustal structure of N-S grabens, marked by highdensity material in the axial regions, separated by basement highs. A large positive gravity anomaly in the basin axes is interpreted as mafic igneous material emplaced into the lower crust (Cooper et al., 1997; Trey et al., 1997). Sedimentary fill in the deep basins is cut by faults and overlapped by a regional unconformity, RU6, that predates thick glacial sediments. The thickness of Mesozoic to early Tertiary sediments is comparatively modest, reaching $4 \mathrm{~km}$ in the Eastern Basin, diminishing toward the coast of MBL (Luyendyk et al., 2001).

In a region of thinned crust but exposed above sea level, the Ford Ranges and Edward VII Peninsula (Figure 2) are key locations for examining the crust that constitutes the WARS and observing the structures responsible for the Cretaceous extension. The oldest rocks exposed are Swanson Formation metagreywacke and Ford Granodiorite of Paleozoic age (Bradshaw et al., 1983; Weaver et al., 1991).
These are intruded by Cretaceous alkalic plutonic rocks (Figure 4) that are genetically linked to the WARS (Weaver et al., 1992, 1994). Lower Paleozoic Swanson Formation represents one of the packages of voluminous quartz-rich turbidites deposited in regionally extensive clastic fans shed from the Ross-Delamerian Orogen (Fergusson and Coney, 1992) or distant Transgondwana orogen (Squire et al., 2006). The rock assemblages that were contiguous along the East Gondwana margin (Figure 3) include the Swanson Formation in MBL (Bradshaw et al., 1983), the western Lachlan Belt in Australia (Glen, 2005), the Robertson Bay group in north Victoria Land (NVL) (Rossetti et al., 2006), and the Greenland Group in NZ (Cooper and Tulloch, 1992; Adams et al., 1995, 2005; Gibson and Ireland, 1996; Adams, 2004; Bradshaw, 2007).

The Swanson Formation was deformed and metamorphosed to low greenschist grade (Adams, 1986) prior to emplacement of latest Devonian to Carboniferous calcalkaline plutons of the Ford Granodiorite (Figure 3) (Adams, 1987; Weaver et al., 1991). Ford Granodiorite represents the first in a succession of convergent margin arcs developed upon the East Gondwana margin from Ordovician through Early Cretaceous time (Pankhurst et al., 1998), and it has correlatives in New Zealand (Muir et al., 1996). Both Swanson Formation and Ford Granodiorite were affected by high-temperature (HT) metamorphism and their high-grade equivalents are exposed in the Fosdick Mountains migmatite gneiss dome (Siddoway et al., 2004b; Saito et al., 2007) (Figure 4). Temperatures in excess of $800^{\circ} \mathrm{C}$, sufficient to cause voluminous melting, were attained two to three times in the history of the dome (Siddoway et al., 2006; Korhonen et al., 2007a,b). The most recent migmatization phase coincided with alkalic plutonism in MBL marked by Byrd Coast granite and mafic dikes (Weaver et al., 1992, 1994; Adams et al. 1995; Siddoway et al., 2005).

Pankhurst et al. (1998) introduced the term "Ross Province" for the Swanson-Ford association in western MBL (Figure 2). Correlatives of the Ross Province exist throughout the former Gondwana margin, including a number of culminations of HT metamorphic rocks derived from Paleozoic protoliths (Tulloch and Kimbrough, 1989; Morand, 1990; Ireland and Gibson, 1998; Vernon and Johnson, 2000; Richards and Collins, 2002; Hollis et al., 2004) (Figure 4). It is probable that Ross-Delamerian orogenic sediments and the intermediate plutonic rocks that intrude them constitute the majority of the crust within the Ross Sea sector of the WARS (Bradshaw, 2007), its continuation into New Zealand (e.g., Cook et al., 1999), and into the submerged extended continental crust bordering the Tasman Sea. Within the WARS crust, there is also sparse evidence of "Ross-aged" basement rocks with an affinity to the TAM (Fitzgerald and Baldwin, 1997; Pankhurst et al., 1998; Bradshaw, 2007). 


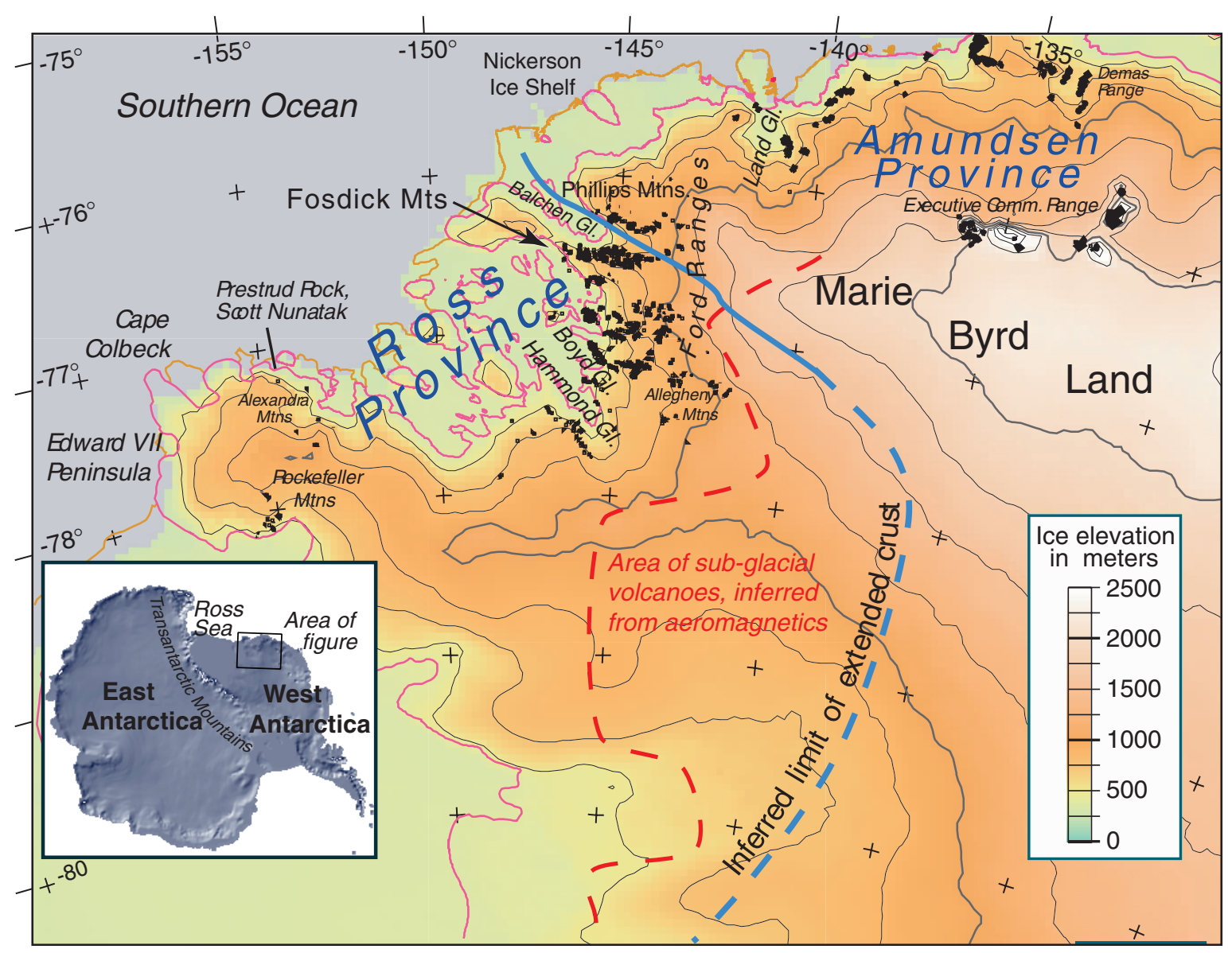

FIGURE 2 Eastern Ross Sea and western Marie Byrd Land location map. Inferred limits of extended crust and a subglacial volcanic field, determined from airborne geophysics (Luyendyk et al., 2003) are indicated. The Ross Province (Pankhurst et al., 1998) of the Ford Ranges comprises lower Paleozoic sedimentary rocks intruded by Devono-Carboniferous intermediate plutons. The rock exposures east of Land Glacier are dominated by intermediate to mafic arc-related plutonic rocks, with subsidiary, younger alkalic intrusions; an association termed the "Amundsen Province" by Pankhurst et al. (1998). Base map by D. Wilson.

\section{THE ACTIVE MARGIN OF EAST GONDWANA AND FORMATION OF THE MESOZOIC WEST ANTARCTIC RIFT SYSTEM}

\section{Convergent Margin Plutonism}

Mesozoic convergent tectonism with intermittent subduction-related plutonism and terrane accretion is recorded in West Antarctica (Vaughan and Livermore, 2005) and contiguous parts of NZ (e.g., Bradshaw et al., 1997). The calc-alkaline, I-type Median Batholith was emplaced in NZ between $145 \mathrm{Ma}$ and $120 \mathrm{Ma}$, with some ages older, to 170 Ma (Muir et al., 1998; Mortimer et al., 1999a,b; Tulloch and Kimbrough, 2003); and tectonic reconstructions show continuity of the magmatic arc, together with associated tectonic terranes, into MBL-Thurston Island (Figure 3) (e.g., Bradshaw et al., 1997). The arc province in MBL, termed the "Amundsen Province" (Pankhurst et al., 1998), was the site of intermediate plutonism spanning the interval 124 to $96 \mathrm{Ma}$ (Pankhurst et al., 1998; Mukasa and Dalziel, 2000).

The timing of HT metamorphism in NZ is determined by $\mathrm{U}-\mathrm{Pb}$ ages on metamorphic zircon or titanite sampled from gneisses at sites distributed along the convergent margin. These include the Paparoa range at 119-109 Ma (Kimbrough and Tulloch, 1989; Ireland and Gibson, 1998; Spell et al., 2000); and Fiordland at 126-110 Ma (Ireland and Gibson, 1998; Hollis et al., 2004; Scott and Cooper, 2006). Granulite metamorphism documented in Fiordland at $108 \pm 3 \mathrm{Ma}$ (Gibson and Ireland, 1995) gives an indication that elevated and compressed crustal isotherms developed during convergent tectonism (Figure 5).

In the Fosdick Mountains gneiss dome in MBL, new U-Pb SHRIMP ages of $115 \pm 1$ Ma have been acquired for igneous zircon within K-feldspar leucogranite equated with anatectic leucosome, that has been sampled at deepest structural levels (Siddoway et al., 2006). Nd isotope data indicate 


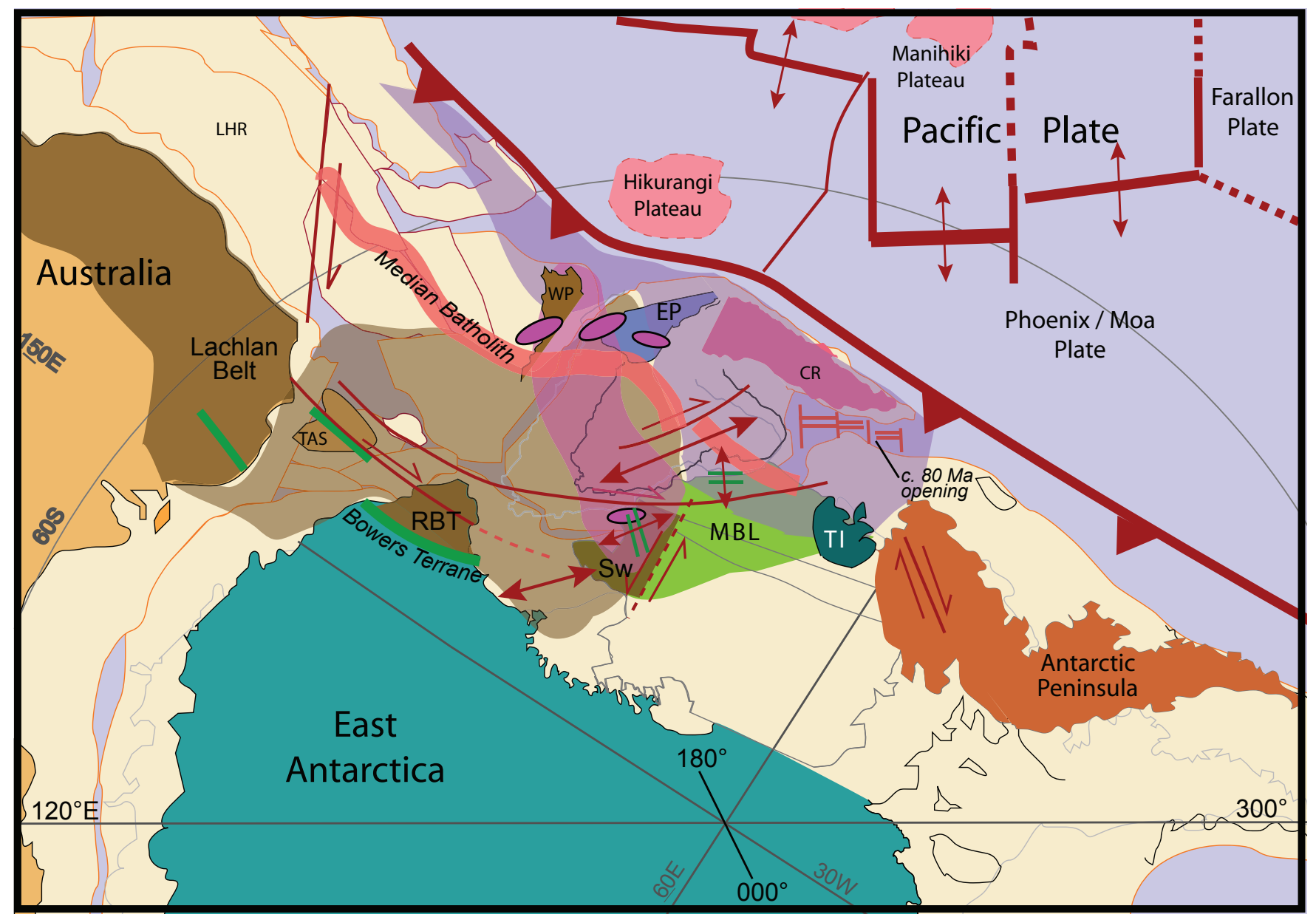

FIGURE 3 Tectonic correlation between terranes of north Victoria Land, West Antarctica, and New Zealand/Campbell Plateau, compiled from Bradshaw (1989) and Bradshaw et al. (1997). Reconstruction of the Cretaceous East Gondwana margin is based on Gaina et al. (1998) and Kula et al. (2007), with oceanic plates configuration based on Sutherland and Hollis (2001) and Larter et al. (2002). Representation of oceanic plateaus is based on Taylor (2006) and Hoernle et al. (2004). Lower Paleozoic orogenic sediments are shown in olive green and tan. Belt of Cretaceous magmatism is shown in violet. Paparoa metamorphic core complex in the Western Province (WP), Fosdick gneiss dome in Marie Byrd Land (MBL), and detachment systems are marked by ellipses. TAS = Tasmania; RBT = Robertson Bay terrane; EP = Eastern Province; $\mathrm{Sw}=$ Swanson Formation; LHR = Lord Howe Rise; $\mathrm{CR}=$ Chatham Rise; $\mathrm{TI}=$ Thurston Island terrane.

a Ford Granodiorite source for the leucogranites (Saito et al., 2007) at $\mathrm{T}, \mathrm{P}$ conditions of $820-870^{\circ} \mathrm{C}$ and $6.5-7.5 \mathrm{kbar}$ determined from mineral equilibria modeling (Korhonen et al., 2007a,b). There is evidence of metamorphic zircon growth as early as ca. $140 \mathrm{Ma}$. A summary of U-Pb SHRIMP analyses of igneous and metamorphic zircon from Fosdick Mountains migmatites (Figure 6) reveals that there is a bimodal distribution of ages. Whereas HT metamorphism and zircon growth is recorded as early as $150 \mathrm{Ma}$, a majority of points analyzed thus far fall within the interval of 120-100 Ma. Anatectic leucosomes from sites in MBL's Amundsen Province, the Demas Range (Figure 2) yield ages of $128 \mathrm{Ma}$ to $113 \mathrm{Ma}$ for igneous zircon (Mukasa and Dalziel, 2000). The MBL data fall within the 126-107 Ma age range of the youngest arc-related intrusions identifid in NZ by Muir et al. (1997,
1998), those of the Separation Point and Rahu suites in the Western Province and the deeper level Fiordland Orthogneiss in Fiordland. The Rahu suite granites are interpreted to derive from crustal melting of preexisting rocks (Ireland and Gibson, 1998). Thus, the conditions for HT metamorphism and granite genesis in the Fosdick Mountains were attained and overlapped in time with arc plutonism in the Median Batholith and in the Amundsen Province.

By contrast, the alkaline plutonism attributed to back-arc extension occurred in eastern MBL (Figure 5) at 105-102 Ma (Weaver et al., 1992, 1994; Mukasa and Dalziel, 2000), distinctly later than onset of high temperature metamorphism. In western MBL the Ford Ranges experienced alkalic plutonism at 105-103 Ma and ca. $99 \mathrm{Ma}$ (Richard et al., 1994) and in Edward VII Peninsula at 103-98 Ma (Mukasa and Dalziel, 


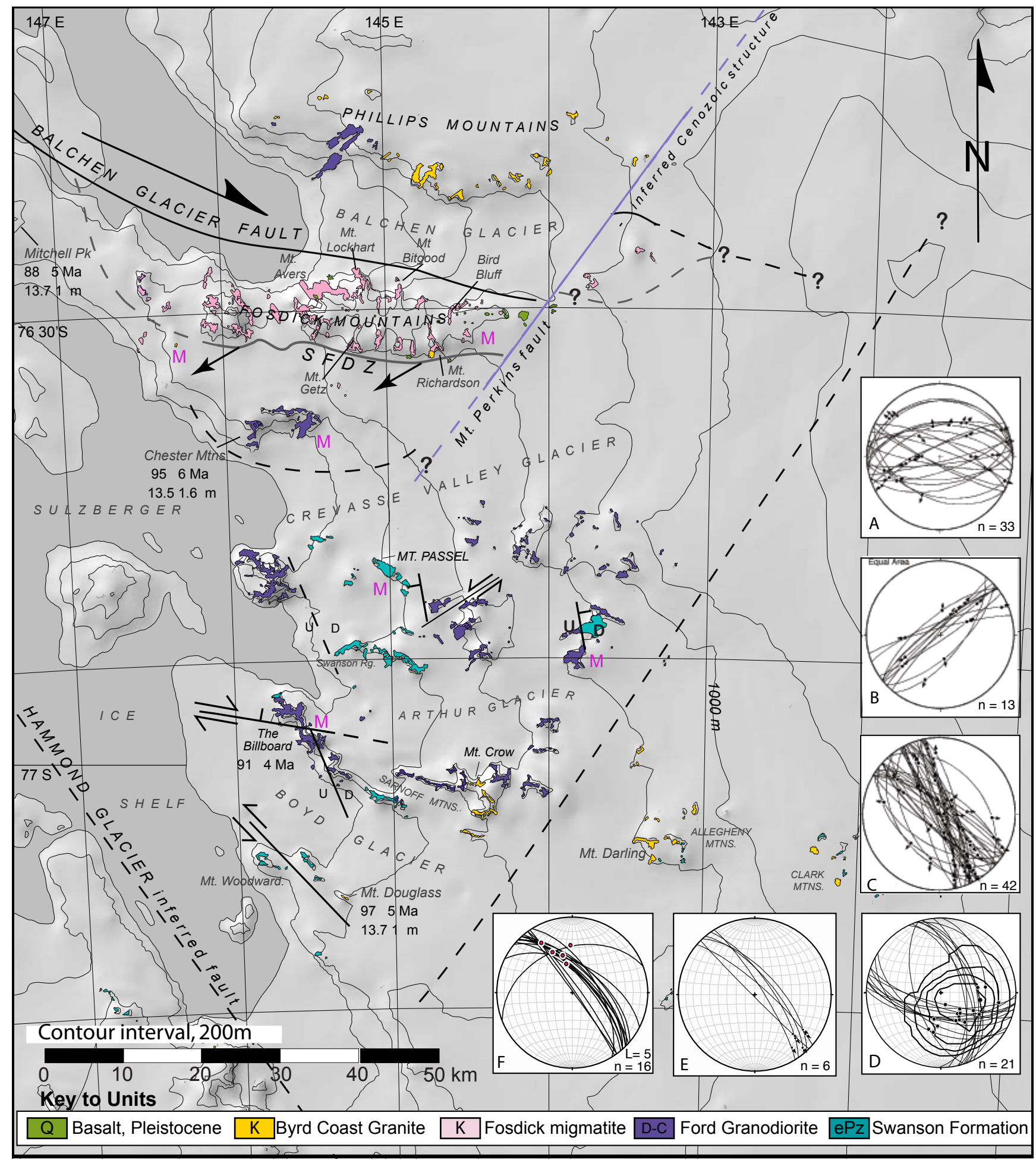

FIGURE 4 Structural-geological map of the Ford Ranges, western Marie Byrd Land. Inferred faults that are concealed by ice are mapped on the basis of contrasts in metamorphic grade between ranges, geophysical lineaments or boundaries, and zones of penetrative brittle deformation in rock exposures. AFT cooling ages and track lengths (Richard et al., 1994; Lisker and Olesch, 1998) are indicated for selected sites. Brittle mesoscopic fault data are shown in stereographic plots (insets). Sites and kinematic sense are as follows: (A) southern Ford Ranges, normal oblique; (B) Mt. Darling, sinistral (Cenozoic); (C) southern Ford Ranges, sinistral oblique; (D) Sarnoff Range, normal oblique; (E) Mt. Crow, sinistral; (F) Mt. Woodward, sinistral oblique. The label "M" indicates sites of glacial deposits examined for clast provenance. Stereonet v. 6.3.3 and FaultKin 4.3.5, by R. Allmendinger 1989-2004, were used for plotting stereographic diagrams. Shaded relief ice topography and base map prepared from Antarctic Digital Database by G. Balco. 

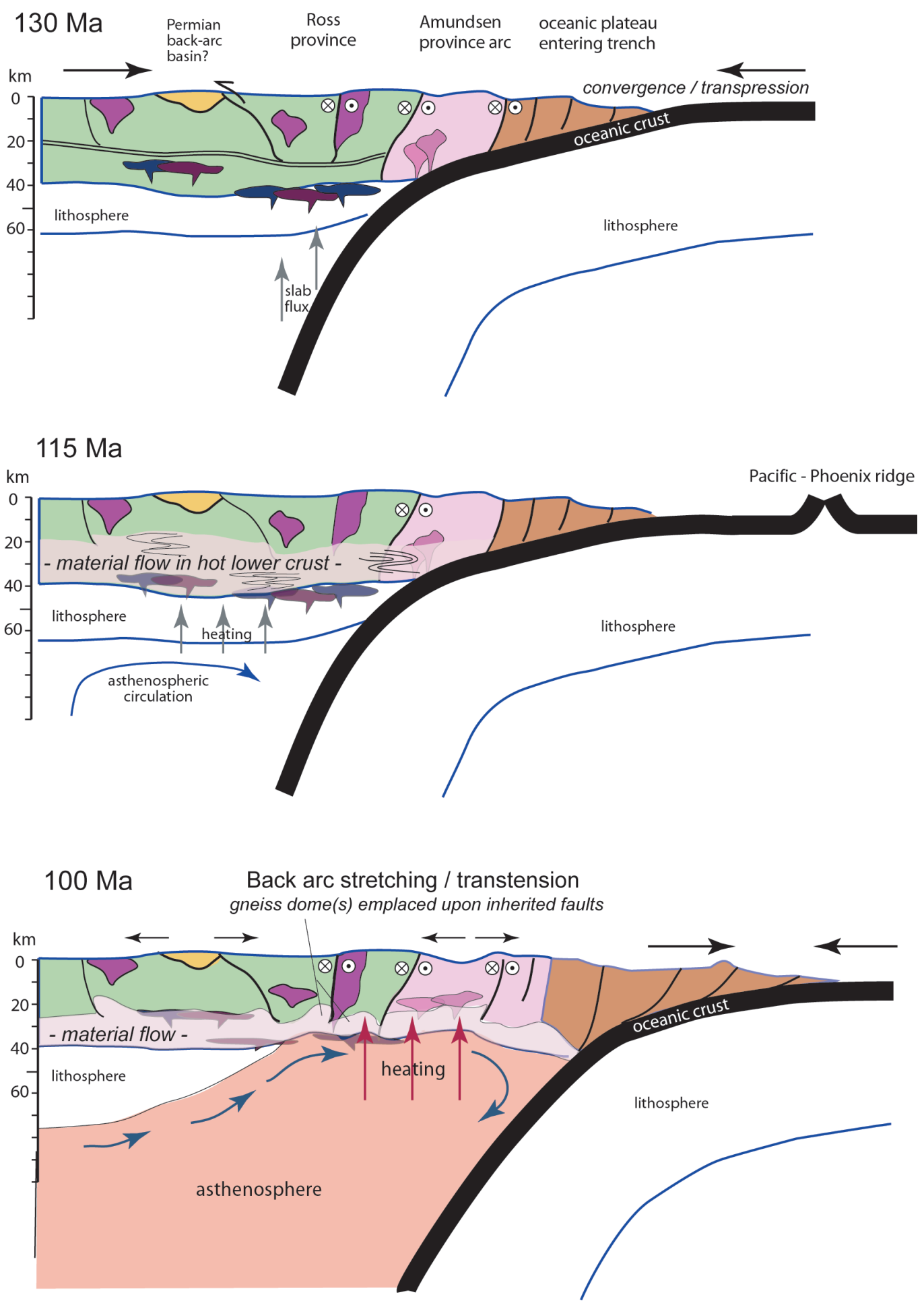

FIGURE 5 Conceptualization for development of the West Antarctic rift system inboard of the Mesozoic convergent margin during oblique plate convergence and subduction of young oceanic lithosphere, including oceanic plateaus. Top: Crustal thickening and advective heating during development of Amundsen province magmatic arc; active margin undergoing transpression due to oblique convergence. Middle: Heating of the lower crust causes partial melting and lateral flow in the middle and lower crust; thermal gradient is increased. Thickening of the crust continues but the lower lithosphere thins. Upper crust undergoes brittle faulting. Bottom: Change to transtension, with oblique opening across preexisting high-angle faults. Lateral flow of hot, weak, partially molten lower crust is accompanied by brittle deformation in shallow upper crust. Strain perturbation along faults allows localized gravity-driven vertical flow of lower-density migmatite-diatexite and formation of gneiss dome(s). Isotherms are elevated, tectonic exhumation and cooling are enhanced, next to transcurrent faults. 
2000; Siddoway et al., 2004a). The dominant plutonic rock is Byrd Coast Granite (Figure 4). Mafic alkalic dikes and syeno-granites were emplaced over a wide region. A dolerite dike swarm at $107 \pm 5 \mathrm{Ma}$ was followed closely by 102-95 Ma syenite and alkalic granite in the Amundsen province (Storey et al., 1999). A wider a range of dike ages, 142 to 96 Ma, comes from the Ross Province (Siddoway et al., 2005). In the Ross province an early phase of Byrd Coast alkalic granite from the Allegheny Mountains is ca. $142 \mathrm{Ma}$, and another at Mt. Corey is $131 \mathrm{Ma}$ (Figure 2) (Adams, 1987). Subduction ceased in New Zealand at $105 \pm 5 \mathrm{Ma}$ (Muir et al., 1994, 1995, 1997, 1998).

Alkalic magmatism in NZ coincided with extension, development of a regional unconformity, and dramatic sedimentation, including thick deposits of sedimentary breccia (Laird and Bradshaw, 2004). Metamorphic core complexes developed in South Island (Figure 3) (Tulloch and Kimbrough, 1989; Forster and Lister, 2003), together with deep level shear zones that were active in Fiordland (Gibson et al., 1988; Scott and Cooper, 2006).

The Lachlan belt on continental Australia and Robertson Bay terrane in NVL occupied an inboard position in middle Cretaceous time and did not experience tectonism related to the active margin (Figure 3), although Australia-EANT breakup was in its initial stages ( $\mathrm{Li}$ and Powell, 2001, and references cited). Remnants of the active margin are the submarine plateaus that border the Tasman Sea and provide a sparse geological record of the change in plate dynamics (Tulloch et al., 1991; Mortimer et al., 1999a, 2006; Mortimer, 2004).

\section{GEOLOGICAL STRUCTURE OF THE FORD RANGES, MARIE BYRD LAND: DATA BEARING ON TECTONISM IN THE WEST ANTARCTIC RIFT SYSTEM}

In MBL the general absence of dynamic fabrics in plutonic units and the elusive nature of crustal-scale faults in a region with extensive ice cover have long hindered the understanding of the strain evolution. New progress has been made in the region through tectonic investigations focused on the structure and metamorphic petrology of the Fosdick Mountains gneiss dome (Siddoway et al., 2004b; Korhonen et al., 2007a; McFadden et al., 2007), the configuration of mafic dikes representing a regional tensile array (Siddoway et al., 2005), and kinematic analysis of mesoscopic brittle faults (Luyendyk et al., 2003). Airborne geophysical data over the Ford Ranges (Luyendyk et al., 2003), and Edward VII Peninsula (Ferraccioli et al., 2002) delineate regional-scale faults. Geochemical investigations reveal the granite petrogenesis (Pankhurst et al., 1998; Mukasa and Dalziel, 2000; Saito et al., 2007) and U-Pb geochronology provide critical age control (Siddoway et al., 2004a,b, 2006; McFadden et al., 2007). A review of the recent findings from MBL in the next section will begin with the lower crustal exposure provided by the Fosdick Mountains, where migmatites provide a view of crustal rheology, kinematics, and dynamics of Cretaceous tectonism that pertain to the West Antarctic rift system as a whole.

\section{The Fosdick Mountains Gneiss Dome}

The Fosdick Mountains form an elongate migmatite gneiss dome (Wilbanks, 1972; Siddoway et al., 2004b) delimited by a S-dipping, dextral-oblique detachment zone on the south (McFadden et al., 2007) and by an inferred steep dextral strike-slip zone on the north, the Balchen Glacier fault (Siddoway et al., 2004b, 2005). From lower to higher structural levels, gneisses that exhibit features indicative of melt-present ductile flow give way to mylonitic rocks exhibiting mixed ductile-brittle deformation textures, indicative of solid-state deformation (McFadden et al., 2007). Kinematic axes calculated from nappe-scale folds and subsidiary folds, mineral lineation, and anisotropy of magnetic susceptibility (AMS) fabrics within the $15 \times 80 \mathrm{~km}$ dome are subhorizontal, 065 to 072 . The orientation is oblique to the long axis of the dome and to the Balchen Glacier fault.

The migmatite gneisses forming the core of the Fosdick Mountains dome reached temperatures $(\mathrm{T})$ and pressures $(\mathrm{P})$ of the upper amphibolite to granulite facies (Siddoway et al., 2004b; Korhonen et al., 2007a). Granite formed by biotite breakdown (Saito et al., 2007) forms sheets, stocks, and extensive interconnected networks on a scale of hundreds of meters. Leucogranite occupies structural sites-within foliation-parallel sheets, shear bands, and interboudin necks-suggestive of deformation-enhanced migration and coalescence of melt products (Sawyer, 2001). Concordant layers of leucogranite may exceed $10 \mathrm{~m}$ in thickness. New U-Pb SHRIMP zircon studies (Siddoway et al., 2004b, 2006; McFadden et al., 2007) and isotope geochemistry (Saito et al., 2007) aid in the task of determining the extent and distribution of anatectic granites formed in Late Cretaceous time, coincident with development of the WARS.

At intervals along the Fosdick Mountains dome, leucogranite sills form vertical sequences that reach $1000 \mathrm{~m}$ in thickness ("leucogranite sheeted complex" of McFadden et al., 2007). The thin layers ( $<1-3 \mathrm{~m})$ of para- and orthogneiss that separate the sills contain microstructures indicative of the former presence of melt and of deformation mechanisms dominated by melt-assisted grain boundary diffusion creep. Kinematic data obtained from the horizons of shallowly dipping paragneiss and orthogneiss include fold axes of symmetrical, tight to isoclinal recumbent folds that trend 062-242 ( $\mathrm{n}=118)$, and sparse mineral lineation aligned 072-252 ( $\mathrm{n}=38$ ) (Siddoway et al., 2004b). The consistent linear data suggest ENE-WSW stretching under suprasolidus conditions when the leucogranite sheets were emplaced. The layers of paragneiss and orthogneiss in this setting are "diatexitic" (Brown, 1973; Milord et al., 2001), in that the color distinction between leucosome and melanosome is subdued, with melanosome a light grey color, and boundaries between 
the light- and darker-colored portions, indistinct. Diatexite textures indicate a high degree of chemical interaction of leucogranite melt with host gneisses under suprasolidus conditions (Sawyer, 1998, 2004). Conventional thermobarometry carried out on the diatexitic paragneisses yielded $\mathrm{P}=4 \mathrm{kbar}$ to $6 \mathrm{kbar}$ and $\mathrm{T}=680^{\circ} \mathrm{C}$ to $780^{\circ} \mathrm{C}$ (Smith, 1992, 1997; Siddoway et al., 2004b). New results of comparative thermobarometry using THERMOCALC indicate considerably higher conditions of $820-870^{\circ} \mathrm{C}$ and $6.5-7.5 \mathrm{kbar}$ for the Cretaceous peak (Korhonen et al., 2007a,b).

The leucogranites exhibit compositional layering and igneous microstructures, such as euhedral grains and tiling of large feldspars; together with evidence of magmatic solid-state deformation (Blumenfeld and Bouchez, 1988; Weinberg, 2006) such as mechanical kinking at grain-tograin contacts in coarse-grained phases. The textures suggest that the interstices between solid phases represented a permeable melt network through which melt flowed. The migmatite structures of the Fosdick Mountains suggest that sills and leucosome networks are remnants of a melt transfer system that allowed magma flux through a zone of anatexis (e.g., Olsen et al., 2005; Weinberg, 2006) within the middle and lower crust (e.g., Brown and Pressley, 1999; Brown, 2007). Deformation aided melt-migration and melt enhanced deformation in a mutually complementary process.

The extensive Cretaceous leucogranites within the gneiss dome contain a dominant population of prismatic igneous zircons. The bipyramidal, elongate zircon grains exhibit oscillatory zoning and lack inheritance, suggesting that they crystallized from a melt. U-Pb SHRIMP ages determined for the zircons are 115-101 Ma (Figure 6), suggesting that elevated temperatures were attained and that melt transfer and crustal flow initiated during middle Early Cretaceous (oblique?) plate convergence, then continued during the transition to extension/transtension in the WARS.

\section{South Fosdick Detachment Zone}

The leucogranitic sheeted complex passes upward into metatexite at highest structural levels on the southern flank of the range. Metatexite (Brown, 1973; Milord et al., 2001; Sawyer, 2004) is a migmatite type that consists of mesoscopic, $\mathrm{cm}$ - to dm-scale compositional layering with a sharp color distinction between light-colored quartzofeldspathic leucosomes and dark, biotite-rich melanosomes. Leucosomes that are volumetrically minor represent a mobile portion, or metatect, and melanosomes, a nonmobilized, depleted component (Brown, 1973; Milord et al., 2001; Sawyer, 2004). Sills and interconnected networks of leucosome that would be indicative of melt transfer and coalescence are poorly developed to absent in the melanosome.

Solid-state deformation is indicated by pervasive mylonitic microstructures indicative of plane strain-simple shear, including C-S fabrics and asymmetric porphyroclasts with tails (McFadden et al., 2007). Kinematic criteria show dextral normal oblique shear sense, with top-to-the-SW transport along azimuth 240. Foliation dips steepen from west toward east, and give way to strong subhorizontal Ltectonite fabrics trending 070-075 within Ford-phase granodiorite at Mt. Richardson (Figure 4). U-Pb SHRIMP zircon data bracket the time of deformation upon the South Fosdick detachment zone between $107 \mathrm{Ma}$ and $96 \mathrm{Ma}$ (McFadden et al., 2007).
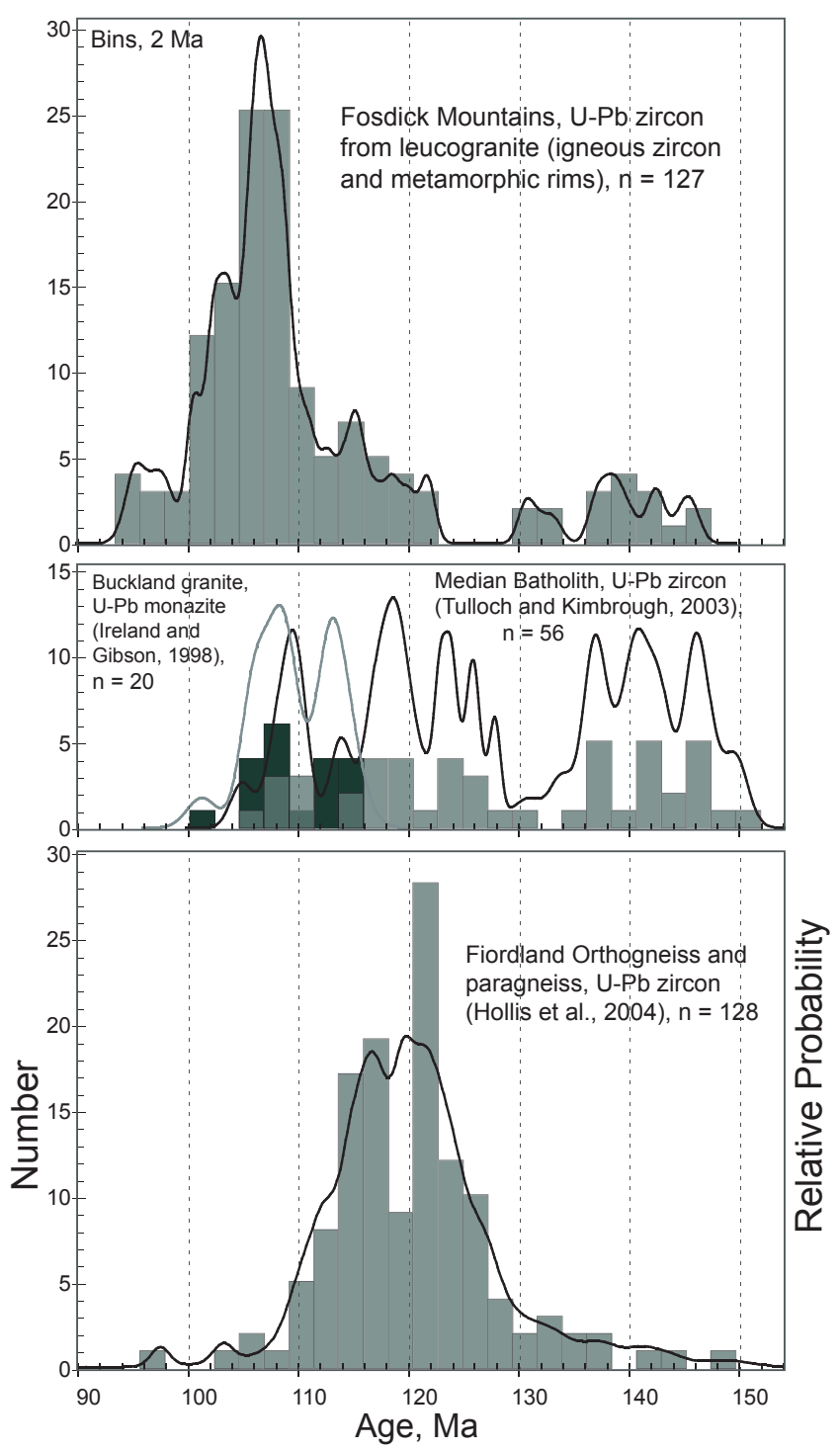

FIGURE 6 Comparison of U-Pb SHRIMP frequency distribution for Fosdick Mountains leucogranites, with New Zealand data including from the Fiordland Orthogneiss (Hollis et al., 2004), Median Batholith (Tulloch and Kimbrough, 2003), and Buckland Granite (Ireland and Gibson, 1998). Fosdick Mountains data were acquired on SHRIMP II at Australian National University under the direction of C. M. Fanning. The relative probability plots with stacked histograms of $206 \mathrm{~Pb} / 238 \mathrm{U}$ ages $(207 \mathrm{~Pb}$ corrected) were calculated using ISOPLOT/EX by K. Ludwig. 
Structural Analysis of Mesoscopic Brittle Fault Arrays Throughout the Ford Ranges

Geometrical and kinematic data have been gathered for systematic mesoscopic brittle structures, including dikes, faults, shear fractures, and joints that cut the isotropic plutonic units, Ford Granodiorite, and Byrd Coast Granite. Structures that cut Byrd Coast Granite or mafic dikes, the majority of which fall in the age range 104-96 Ma, are known to be middle Cretaceous or younger. Mesoscopic faults are striated planes accommodating $>2 \mathrm{~m}$ offset or zones of cataclasis exceeding $15 \mathrm{~cm}$ thickness. The term "shear fractures" refers to slickenside surfaces, sometimes mineralized but generally lacking gouge, and rarely associated with geological markers that allow quantification of offset. In most instances, therefore, brittle criteria are used for interpretation of shear sense (Marrett and Allmendinger, 1990). Few data come from Swanson Formation, because brittle shear planes typically reactivated bedding or preexisting cleavage, making the kinematic significance uncertain.

Outside of the Fosdick Mountains migmatite dome most exposures of crystalline rocks in the Ford Ranges lack dynamic fabrics (Siddoway et al., 2005) and mylonitic zones are found only rarely. Four sites hosting ductile shear zones are situated near locations for which thermochronology data are now available (Table 1). Narrow mylonitic shear zones (1-5 m wide) cut Ford Granodiorite at Mt. Crow (Figure 4, inset E) and Mt. Cooper (Siddoway et al., 2005). High-temperature shear zones exist along the present-day Ross Sea coast, at Mt. Woodward (60 m exposed width) (Figure 4, inset F) and at Prestrud Rock (30 m minimum width). Each of the sites is adjacent to an inferred crustal-scale strike-slip zone that is concealed by ice (Ferracioli et al., 2002; Luyendyk et al., 2003; Siddoway et al., 2005).

Mafic dikes provide a very valuable kinematic dataset due to their regional distribution and very consistent regional orientation of azimuth 344, subvertical, throughout the Ford Ranges. Tensile opening perpendicular to the dike margins is a reflection of ENE stretching at the time of emplacement. The dike array cuts Byrd Coast granite of 102-98 Ma age, and the range of ${ }^{40} \mathrm{Ar}{ }^{39} \mathrm{Ar}$ ages for the majority of the mafic dikes is 104-96 Ma (groundmass concentrates on microcrystalline dikes; Siddoway et al., 2005). U-Pb titanite and ${ }^{40} \mathrm{Ar}{ }^{39} \mathrm{Ar}$ hornblende ages for discordant mafic dikes within the Fosdick range are 99-96 Ma (Richard et al., 1994; Siddoway et al., 2006). Mutually crosscutting relationships between mafic dikes and faults indicate that they are contemporaneous.

Brittle fault data offer the most tenuous data to interpret due to the paucity of offset markers and the need to use brittle criteria for kinematic shear sense. Nonetheless, consistent fault and shear fracture arrays are identified. In the central and southern Ford Ranges a well-defined $\sim \mathrm{NW}$-SE-oriented conjugate fault array hosts moderately oblique, SE-plunging striae on both SSW and NE dipping planes (Figure 4, inset D). The array is expressed both as minor faults and shear fractures with kinematic criteria indicative of oblique slip, with top-to-the-ESE translation (Luyendyk et al., 2003). The dominant orientation in this array is ESE-striking, with dextral normal oblique kinematic sense. A second generation of brittle structures in the Sarnoff and Denfield ranges consists of NNW-striking, normal- to oblique-slip shear fractures (Figure 4, inset C). The widespread NNW-oriented mesoscopic structures have strikes parallel to the regional mafic dike array, and to the prevalent fault orientations offshore in the easternmost Ross Sea (Luyendyk et al., 2001; Decesari et al., 2003). A late ENE-oriented array is strongly expressed in the Chester Mountains (Figure 4), forming chloritic brittle shear zones up to $15 \mathrm{~cm}$ in width, and chloritic and oxidized shear fractures. Brittle criteria on the planes oriented N75E (mean) indicate normal dextral oblique slip upon SSW- and NNEtrending striae (Figure 4, inset A).

NE-oriented, sinistral strike-slip shears are spatially associated with inferred Cenozoic faults that trend NE-SW and offset the Fosdick Mountains gneiss dome (Figure 4, inset B). Pleistocene mafic lavas erupted from small volcanic centers along the trend (Gaffney and Siddoway, 2007) (Figure 4). A brittle fault data set comes from the series of outcrops forming the easternmost exposures in the Ford Ranges, which is situated near a prominent NE-trending escarpment imaged in the bedrock topography (Luyendyk et al., 2003) that corresponds with a geophysical anomaly arising from inferred sub-ice volcanic centers (Figure 7). These are NE-SW shear fractures with strike slip striae, with consistent sinistral-sense offset from brittle kinematic criteria (Figure 4, inset B).

With respect to timing, regional deformation caused by mid-crustal flow arising from melt accumulation in the lower and middle crust (Figure 8) was under way as early as 115 Ma, based on the ages determined for melt-present deformation in the lower crustal exposures in the Fosdick Mountains rocks. The older limit on the time of brittle deformation and formation of mylonitic zones in the upper crustal rocks of the Ford Ranges is provided by Cretaceous plutonic rocks of 104-96 Ma age (Byrd Coast granite and mafic alkalic dikes) that are cut by brittle faults. The cooling history of the block-faulted mountain ranges constrained by ${ }^{40} \mathrm{Ar} /{ }^{39} \mathrm{Ar}$ and apatite fission track thermochronology (summarized below) provides a younger age limit on regional tectonism.

\section{Crustal Structure from Airborne Geophysics}

Airborne gravity and radar soundings over western MBL indicate that the crustal thickness beneath the Ford Ranges is $22-25 \mathrm{~km}$, increasing to the north and inland by $8-9 \mathrm{~km}$ for central MBL (Figure 2) (Luyendyk et al., 2003). The inferred steep gradient in crustal thickness coincides spatially with the linear northern front of the Fosdick Mountains, where migmatites were exhumed from mid-crustal 
TABLE 1 Summary of 40Ar/39Ar and AFT Thermochronology Data for Sites in the Central and Eastern West Antarctic Rift System

\begin{tabular}{|c|c|c|c|c|c|c|c|}
\hline Location & Feature & Age (Ma) & $\begin{array}{l}\text { AFT Track } \\
\text { Length }(\mathrm{mm})\end{array}$ & Method & Source of Data & Field Association & Kinematics \\
\hline Ford Ranges & Mafic dikes & $104-96$ & n.a. & $\begin{array}{l}{ }^{40} \mathrm{Ar} /{ }^{39} \mathrm{Ar} \\
\text { groundmass }\end{array}$ & $\begin{array}{l}\text { Siddoway et } \\
\text { al., } 2005\end{array}$ & $\begin{array}{l}\text { Tabular, vertical to } \\
\text { sub-vertical dikes } \\
\text { throughout the } \\
\text { Ford Ranges }\end{array}$ & Tensile, 074-254 \\
\hline Mt. Cooper & Mylonite zone & $96.92 \pm 0.34$ & n.a. & ${ }^{40} \mathrm{Ar} /{ }^{39} \mathrm{Ar}$ biotite & $\begin{array}{l}\text { Siddoway et } \\
\text { al., } 2005\end{array}$ & $\begin{array}{l}\text { 3- to 5-m-wide } \\
\text { zone cutting Ford } \\
\text { Granodiorite }\end{array}$ & $\begin{array}{l}\text { Normal sense, } \\
\text { down to East }\end{array}$ \\
\hline Prestrud Rock & Gneiss & $91 \pm 4$ & $13.1 \pm 0.2$ & AFT & $\begin{array}{l}\text { Lisker and } \\
\text { Olesch, 1998; } \\
\text { Smith, } 1996\end{array}$ & $\begin{array}{l}\text { Contrast in grade } \\
\text { and fabrics; strong } \\
\text { lineation suggest } \\
\text { shear zone }\end{array}$ & $\begin{array}{l}\text { Strike oblique; } \\
\text { kinematic sense } \\
\text { not determined }\end{array}$ \\
\hline The Billboard & $\begin{array}{l}\text { Unfoliated Ford } \\
\text { granodiorite }\end{array}$ & $91 \pm 4$ & n.a. & AFT & $\begin{array}{l}\text { Lisker and } \\
\text { Olesch, } 1998\end{array}$ & $\begin{array}{l}\text { Ford granodiorite } \\
\text { bounded by an } \\
\text { inferred east-west } \\
\text { fault; borders } \\
\text { inferred east-west } \\
\text { fault }\end{array}$ & $\begin{array}{l}\text { Strike normal } \\
\text { oblique, inferred } \\
\text { dextral }\end{array}$ \\
\hline Mt. Douglass & $\begin{array}{l}\text { Unfoliated Byrd } \\
\text { Coast granite }\end{array}$ & $97 \pm 5$ & $13.7 \pm 0.2$ & AFT & $\begin{array}{l}\text { Lisker and } \\
\text { Olesch, } 1998\end{array}$ & $\begin{array}{l}\text { Unfoliated Byrd } \\
\text { Coast granite, } \\
\text { located } 6 \mathrm{~km} \\
\text { from shear zone } \\
\text { in calcsilicate } \\
\text { gneisses at Mt. } \\
\text { Woodward }\end{array}$ & $\begin{array}{l}\text { Sinistral oblique } \\
\text { sense; shear zone } \\
>100 \mathrm{~m} \text { wide }\end{array}$ \\
\hline $\begin{array}{l}\text { Chester } \\
\text { Mountains }\end{array}$ & $\begin{array}{l}\text { Unfoliated Ford } \\
\text { granodiorite }\end{array}$ & $95 \pm 6$ & 13.5 & AFT & $\begin{array}{l}\text { Lisker and } \\
\text { Olesch, } 1998\end{array}$ & Ford granodiorite & $\begin{array}{l}\text { Hanging wall of } \\
\text { South Fosdick } \\
\text { detachment }\end{array}$ \\
\hline Mitchell Peak & Migmatite gneiss & $88 \pm 5$ & $14.2 \pm 0.1$ & AFT & $\begin{array}{l}\text { Lisker and } \\
\text { Olesch, } 1998\end{array}$ & Migmatite gneiss & $\begin{array}{l}\text { Hanging wall of } \\
\text { South Fosdick } \\
\text { detachment }\end{array}$ \\
\hline
\end{tabular}

NOTE: n.a. = not applicable; AFT = Apatite fission track; DSDP = Deep Sea Drilling Project. Kinematic determinations from Siddoway et al., 2005, or Siddoway, unpublished.

depths. A steep gradient also is observed in the magnetics, and there is a well-defined lineament in the bedrock topography beneath Balchen Glacier (Figures 2 and 7). Presentday bed topography for much of the surveyed area defines distinct NNW-SSE and NE-SW-oriented lineaments that are oblique to the density distributions. They are generally parallel to the NNW-oriented, normal-sense and NE-striking, sinistral-sense, second generation shear fractures measured throughout the Ford Ranges and to the mafic dike array. High-gradient magnetic anomalies inferred to be subglacial volcanoes of Cenozoic age are mapped to the east (Figures 2 and 4) (Luyendyk et al., 2003), and are spatially associated with a postulated NE-SW strike slip fault of Cenozoic age (Siddoway et al., 2005) (Figure 4).

Linear magnetic anomalies on Edward VII Peninsula have three dominant trends. They trend $\sim \mathrm{E}-\mathrm{W}, \mathrm{NNW}$, and NE (Ferraccioli et al., 2002). Outlet glacier troughs in the southern Ford Ranges and Edward VII Peninsula appear to be controlled by the NNW trend (Luyendyk et al., 2001; Wilson and Luyendyk, 2006; Sorlien et al., 2007), and have a narrow, deep linear morphology that suggests an association with the regional normal fault array.

Magnetic and gravity anomalies together with bedrock topography calculated from airborne geophysics data 
(Luyendyk et al., 2003) provide the means to assess the regional significance of structures identified from outcrop study. Conversely, information from geological structures may clarify the kinematic history of subglacial features inferred from geophysics. A pattern of generally east-westoriented gravity anomalies, interpreted as pronounced density variations in the bedrock, is identified in the Ford Ranges and further south (Figure 7). Their trends generally correspond to the approximately east-west orientation of mountain ranges and outlet glaciers in the central and northern Ford Ranges, which have long been considered to be structurally controlled (e.g., Luyendyk et al., 1994).

The margins of the low-density areas are distinct and fairly linear over tens of kilometers, and are parallel to each other, with a nearly E-W trend (Figure 7). Their orientation is parallel or subparallel to the elongate, ESE-trending, low-gradient magnetic anomaly over the Fosdick dome (Luyendyk et al., 2003), and to the known crustal-scale faults bounding the Fosdick Mountains (Siddoway et al., 2004b, 2005; McFadden et al., 2007). Kinematic data within the dome and from neighboring exposures that represent the brittle upper crust show that the dome-bounding faults accommodated dextral to dextral oblique motion. The correspondence of the limits of linear gravity anomalies with the north and south faults bounding the Fosdick migmatite dome suggest that the pattern of generally E-W gravity anomalies over the Ford Ranges and eastern MBL, more broadly, are controlled by dextral oblique faults that dropped cover rocks down with respect to crystalline rocks.

A possible interpretation of the E-W-trending, regular variations in density (Figure 7) is that they correspond to sedimentary basins and intervening highs that originated during Late Cretaceous development of the WARS. A number of observations suggest that this is not the case. First of all, sharply defined features in the sub-ice topography do not correspond to the boundaries separating regions of contrasting density (Luyendyk et al., 2003), as might be expected if comparatively young, poorly indurated clastic sediments existed at depth. Furthermore, no Late Cretaceous-Eocene sedimentary or volcanic strata crop out in Marie Byrd Land (see Pankhurst et al., 1998), and the makeup of glaciertransported clasts within bouldery till upon bedrockdetermined from careful searches at six sites bordering three outlet glaciers (labeled "M" in Figure 4)—is dominated by greenschist-grade Swanson Formation, with a small proportion of Byrd Coast Granite and Ford Granodiorite clasts. The prevalence of Swanson Formation clasts and absence or low abundance of younger clastic rocks favors the hypothesis that Swanson Formation constitutes the bedrock beneath the glacier drainages that traverse three of the low-density regions within the Ford Ranges (Figure 7).

The apparent absence or low abundance of Late Cretaceous-Paleocene sedimentary deposits on land is enigmatic, in light of the WARS extension of $>100$ percent and the subsequent breakup between MBL and NZ. Possibly the region experienced an interval of low sediment supply (Karner et al., 2005), or did not develop significant relief above or subside below sea level (e.g., LeMasurier and Landis, 1996; Luyendyk et al., 2001).

To summarize, the findings from aerogeophysical surveys and structural geology studies in the region suggest that the brittle crustal architecture along the eastern margin of the Ross Sea rift developed through NE-SW regional transtension upon high-angle faults, with extensional strain accommodated upon NNW-striking mafic dikes and normal faults, and wrench deformation occurring upon a conjugate array of approximately E-W-oriented dextral strike slip zones, and NE-SW sinistral strike slip faults (Figure 4), affecting Cretaceous and older rock units (Ferraccioli et al., 2002; Luyendyk et al., 2003). Generally E-W-oriented crustal-scale structures in the northern Ford Ranges may have originated as contractional faults during prior NNE-SSW convergence along the East Gondwana margin in the Mesozoic Era or before. The correspondence to inferred geological boundaries between supracrustal and crystalline rocks is a possible indication that Paleozoic structures were reactivated during opening of the WARS.

\section{Thermochronology and Cooling History of the WARS}

${ }^{40} \mathrm{Ar} /{ }^{39} \mathrm{Ar}$ and apatite fission track (AFT) data for sites distributed across the West Antarctic rift system are beginning to reveal the regional cooling pattern for the WARS. Sample sites (Figures 1 and 2) include DSDP 270 on the Central High (Fitzgerald and Baldwin, 1997), Colbeck Trough on the eastern margin of Ross Sea (Siddoway et al., 2004a), Edward VII Peninsula and the southern Ford Ranges (Adams et al., 1995; Lisker and Olesch, 1998), and the Fosdick Mountains (Richard et al., 1994). ${ }^{40} \mathrm{Ar} /{ }^{39} \mathrm{Ar} \mathrm{K}$-feldspar data available from three sites record cooling at $98 \mathrm{Ma}$ to $94 \mathrm{Ma}$ (Table 1) (Figure 4). The AFT data record rapid cooling across the region by ca. $90 \mathrm{Ma}$, but also show complexity in the cooling histories that cannot be explained by a single event. AFT data fall within two age populations of 97-88 Ma and 80-70 Ma, each characterized by long track lengths indicative of rapid cooling (Table 1).

Diachronous cooling was first noted by Richard et al. (1994) for the Fosdick Mountains. Migmatites rapidly cooled through ${ }^{40} \mathrm{Ar} /{ }^{39} \mathrm{Ar}$ closure temperatures for four mineral phases, having equilibrated at $\mathrm{T}>700^{\circ} \mathrm{C}$ at ca. $101 \mathrm{Ma}$, then cooled to $\mathrm{T}<165^{\circ} \mathrm{C}$ by ca. $94 \mathrm{Ma}$. The AFT study determined long track lengths indicative of rapid cooling, but the AFT ages are considerably younger at 76-67 Ma. Thus the thermochronology data suggest two pulses of cooling due to tectonic exhumation of the Fosdick Mountains gneiss dome, separated by a quiescent interval. Additional AFT data over the broader region confirm the bimodal distribution of ages of 97-88 Ma and 80-70 Ma in the Ford Ranges, Edward VII Peninsula (Adams et al., 1995; Lisker and Olesch, 1998), and central Ross Sea (Fitzgerald and Baldwin, 1997). 
New mapping and structural geology research reveals that seven of the sites recording the older AFT or ${ }^{40} \mathrm{Ar} /{ }^{39} \mathrm{Ar}$ ages (Table 1) are situated near regional-scale faults or within shear zones. These include Prestrud Rock, bordering the Ross Sea at the edge of the Alexandra Mountains (Figure 2) (Smith, 1996; Ferracioli et al., 2002); the Colbeck trough on the margin of Edward VII Peninsula (Figure 2) (Siddoway et al., 2004a); and DSDP site 270 on the Ross Sea Central High (Figures 1 and 9) (Fitzgerald and Baldwin, 1997). Adams et al. (1995) attributed a pronounced contrast in cooling history between the Alexandra and Rockefeller Mountains to relative fault motion. The two off-shore sites correspond to inferred detachment faults submerged along the eastern margin and Central High of the Ross Sea (Fitzgerald and Baldwin, 1997; Siddoway et al., 2004a). The tectonites from both offshore sites exhibit ductile fabrics overprinted by brittle cataclasis, suggestive of translation from deeper to shallower crustal levels. No geometrical or kinematic

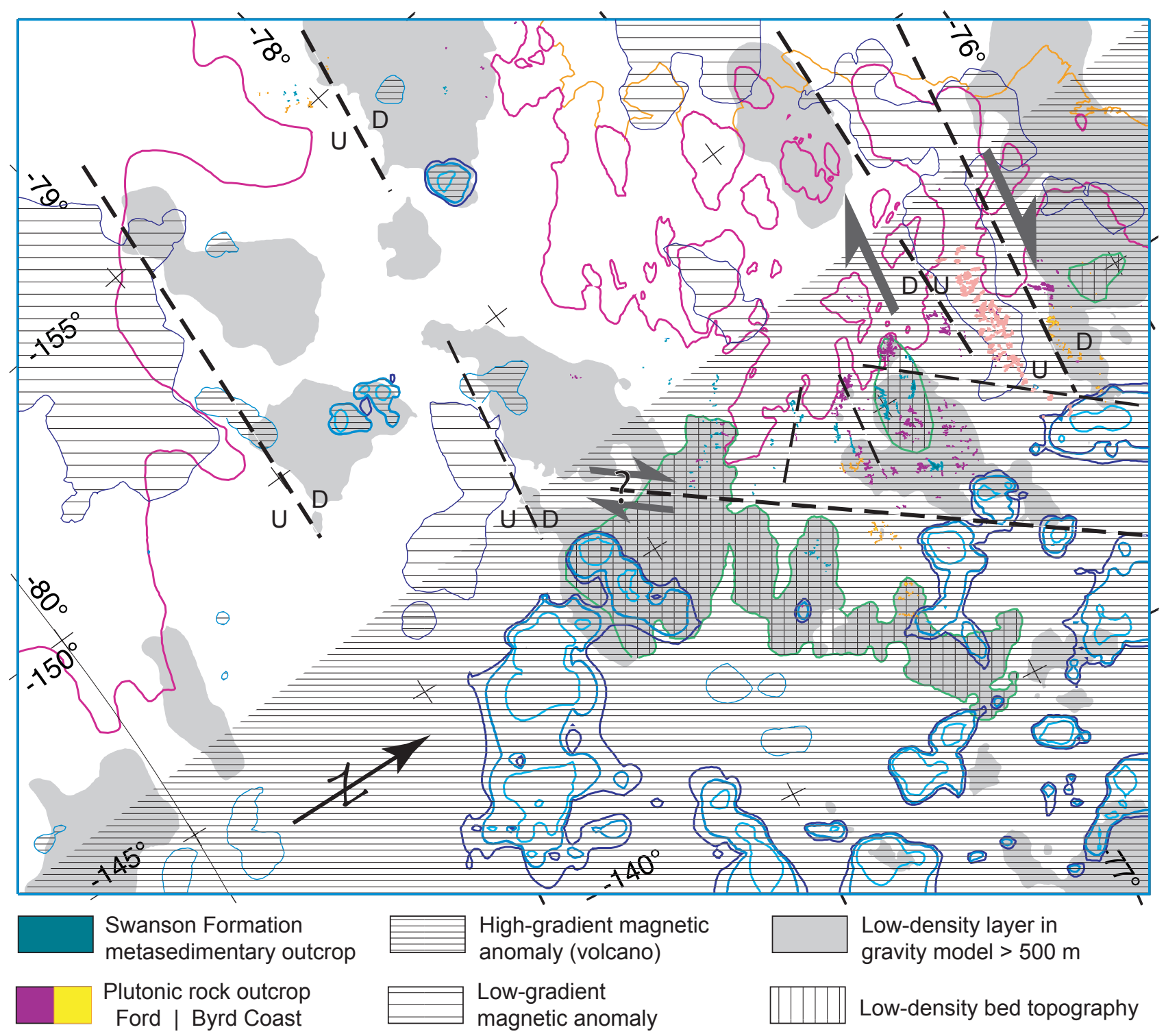

FIGURE 7 Summary diagram of potential fields data and modeling (Luyendyk et al., 2003) for the region surveyed by the Support Office for Aerogeophysical Research in 1998. North direction is toward the upper right. High-gradient positive magnetic anomalies delimited by the $+50 \mathrm{nT}$ contour are interpreted as subglacial volcanic centers. Broader, lower-gradient positive magnetic anomalies are attributed to crustal magnetization contrasts. Gray-shaded areas correspond to low-density regions $\left(2300 \mathrm{~kg} / \mathrm{m}^{3}\right)$ exceeding $500 \mathrm{~m}$ thickness, determined from gravity modeling (Luyendyk et al., 2003). Small polygons filled with solid color are rock exposures. Dashed straight lines are inferred faults between crust with low-density bodies and crust with sources of low-gradient magnetic anomalies. Modeling carried out by D. Wilson, University of California, Santa Barbara. 
information was obtained for the structures since sample retrieval was by drill core (Ford and Barrett, 1975; Hayes and Davey, 1975) and dredge (Luyendyk et al., 2001). DSDP 270 yielded a multicomponent AFT sample from a few grains of apatite extracted from calcsilicate gneiss $(n=16)$ (Fitzgerald and Baldwin, 1997). The dominant component is $90 \pm 6 \mathrm{Ma}$ in age.

A recently discovered shear zone site that yields critical kinematic data is at Mt. Woodward, bordering a pronounced lineament along the Haines Glacier (Figure 4, inset F). The steep high-strain zone developed in high-temperature calcsilicate gneisses is oriented 160-340 and exceeds 100 $\mathrm{m}$ in width. Asymmetrical folds indicate sinistral shear sense (Siddoway, unpublished). The thermochronology data obtained from Mt. Douglass, $6 \mathrm{~km}$ away, yield the region's oldest AFT cooling age of $97 \pm 5$ Ma on Byrd Coast granite (Lisker and Olesch, 1998). Northwest-southeast-oriented bedrock faults are inferred to control the Sarnoff Range trend, where pronounced narrow troughs, oriented 150330 , are evident in the bedrock topography (Luyendyk et al., 2003). A 3-m-wide mylonitic shear zone at Mt. Crow (Figure 4, inset E) parallels this trend and offers kinematic information that possibly is representative of the concealed fault. The Mt. Crow shear zone exhibits shallow-plunging sinistral-sense stretching lineation oriented 20,138, on steep foliation. An AFT age of $91 \pm 4 \mathrm{Ma}$ (Lisker and Olesch, 1998) came from Ford Granodiorite at The Billboard in the Sarnoff Range (Figure 4).

The remaining sites with AFT data in the older age range (Table 1) are associated with the hanging wall of the South Fosdick detachment zone. They are Mitchell Peak, the isolated nunatak forming the westernmost outcrop in the Fosdick range, and the Chester Mountains, south of the Fosdick range (Figure 4). There is a pronounced contrast in cooling age across the South Fosdick detachment zone (Figure 4), with $95 \mathrm{Ma}$ to $88 \mathrm{Ma}$ AFT ages obtained from sites in the hanging wall, and $76 \mathrm{Ma}$ to $67 \mathrm{Ma}$ from sites in the gneiss dome core (Table 1).

Remaining AFT localities in western MBL record moderate to slow cooling between $83 \mathrm{Ma}$ and $67 \mathrm{Ma}$. The ages correspond to the time of initiation of seafloor spreading between Campbell Plateau (NZ) and WANT (Figure 1) at 83-79 Ma (chron 33r) (McAdoo and Laxon, 1997; Larter et al., 2002; Stock and Cande, 2002; Eagles et al., 2004), suggesting that the second AFT cooling pulse was triggered by the lithospheric separation (Figure 9c) (Siddoway et al., 2004a; Kula et al., 2007). There is a good correspondence in timing and tectonic history of MBL localities with detachment structures in New Zealand (Kula et al., 2007).

In summary, examination of AFT data together with mapped structures shows that the early stage of rapid cooling in western Marie Byrd Land at 95-85 Ma was localized upon high-angle conjugate wrench zones. The timing of fault activity determined from U-Pb zircon geochronology, ${ }^{40} \mathrm{Ar} /{ }^{39} \mathrm{Ar}$, and AFT thermochronology corresponds with the time of development of the eastern WARS. The younger phase of rapid cooling at $\sim 75 \mathrm{Ma}$ reflects regional uplift and cooling, coincident in time with and attributable to modest denudation in response to onset of seafloor spreading and separation between WANT and New Zealand, upon a new divergent plate boundary that continued in to the Tasman Sea (Figure 3a) (Gaina et al., 1998; Sutherland, 1999; Kula et al., 2007). The observation that rapid cooling occurred first upon discrete WARS fault zones (101-92 Ma) suggests a localized landscape response, reflected in the thermochronology cooling histories data. The affected area covers $250,000 \mathrm{~km}^{2}$ of western Marie Byrd Land and the neighboring Ross Sea.

\section{DISCUSSION}

The Role of a Hot Middle Crust in the Regional Structural Evolution of the WARS

The Fosdick Mountains gneiss dome is a structure of vast complexity pervaded by sills and discordant networks of leucogranite. Crosscutting relationships and varying degrees of deformation suggest multiple cycles of melt migration and emplacement within structurally controlled, dilatant sites. Thick sills of leucogranite containing microstructures indicative of horizontal magmatic flow are interlayered with thin sheets of diatexitic gneisses that exhibit consistent ENEWSW kinematic sense, leading to the interpretation that the Fosdick gneiss dome represents an exposure of deep middle crust that underwent directional viscous, magma-like flow (Figure 8).

Relationships in the Fosdick Mountains dome suggest that partial melting and rheological weakening of the crust in MBL was a consequence of crustal heating during orogenesis, affecting "Lachlan"-type sedimentary rocks and middle Paleozoic intermediate plutons. Argillaceous rocks of Lachlan type are chemically fertile (e.g., Thompson, 1996) and may generate substantial quantities of melt. Subjected to a differential stress in a convergent orogen or to gravity forces in the region of thickened crust at the convergent margin, viscous flow commenced (Figures 5 and 8). The localization of strain at the interface between the region of hot versus cold crust caused detachment structures to initiate (Figure 8b) (e.g., Teyssier et al., 2005) and/or reactivated preexisting faults (Siddoway et al., 2004b, 2005), leading to gneiss dome emplacement (Figure 8c).

The development of thermal perturbations of this type in a convergent margin setting has been noted as a characteristic of hot accretionary orogens (Collins, 2002a). The Lachlan belt exemplifies this type of orogen as it has undergone multiple cycles of contractional orogeny and extensional collapse involving HT metamorphism (Foster et al., 1999; Collins, 2002a,b; Gray and Foster, 2004; Fergusson et al., 2007). In MBL the elevated heat flow into the base of the continental crust may have arisen during subduction of hot oceanic lithosphere newly formed at the Phoenix-Pacific 
Transpression during plate convergence

Northeast

Southwest

Thickened crust

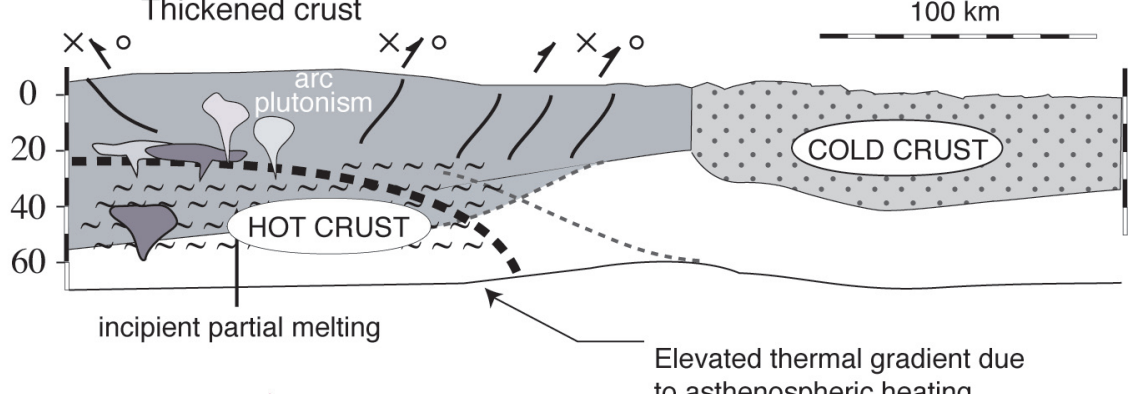

Elevated thermal gradient due
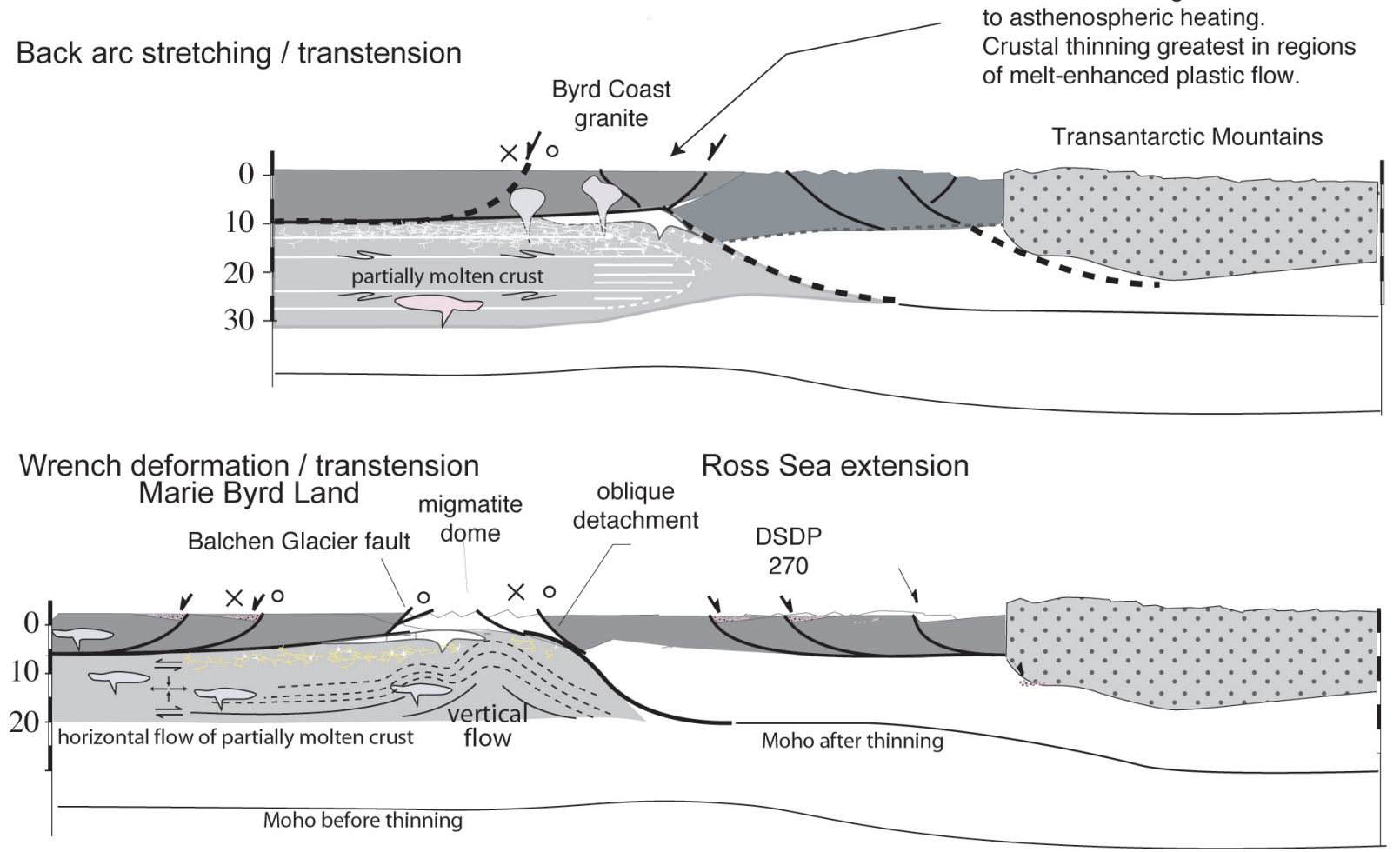

FIGURE 8 Cross-sections illustrating the consequences of presence of a hot, weak, partial melt-rich horizon in the lower crust. Portrays the geometry and kinematics of brittle structures in the upper crust and propagation of viscous flow region within the middle to lower crust. Top: Crustal heating and crustal thickening within convergent margin setting, wrench faults active. Middle: Partially molten crust flows laterally, advecting heat into new regions and weakening the crust. Bottom: Transtension affects a large region of warm crust near the active margin. Sites of melt transfer and accumulation exhibit vertical translation if focused upon a fault. X, O symbols indicate motion out of and in to the plane of the profile.

ridge (Figures 4 and 5b) (Bradshaw, 1989; Luyendyk, 1995), or due to back arc extension and lithospheric thinning (Figure 5b and 5c) (Weaver et al., 1991, 1994; Mukasa and Dalziel, 2000); or from basal heating in the presence of a postulated mantle plume (Weaver et al., 1994). Singly or collectively these factors could promote magmatic underplating and advection of heat into the crust, with corresponding effects on crustal rheology (Regenauer-Lieb et al., 2006). Further effects could arise from infiltration of fluids into the overriding plate due to dehydration of the newly subducted slab, or to radiogenic heat production in the East Gondwana crust that had been thickened during Mesozoic convergence (e.g., Collins and Hobbs, 2001; McKenzie and Priestly, 2007), augmented by heat advection by fluids. The rheological partitioning interpreted to exist in the Cenozoic WARS, with a brittle to ductile gradient across the Ross Sea (Salvini et al., 1997) may have been established at this time.

The question of whether the substantial volumes of leucogranite derived from constituent gneisses of the Fosdick dome (phases of Ford Granodiorite, Swanson Formation) or were produced within other parts of a crustal zone of magma flux (e.g., Olsen et al., 2005) then migrated into the dome 

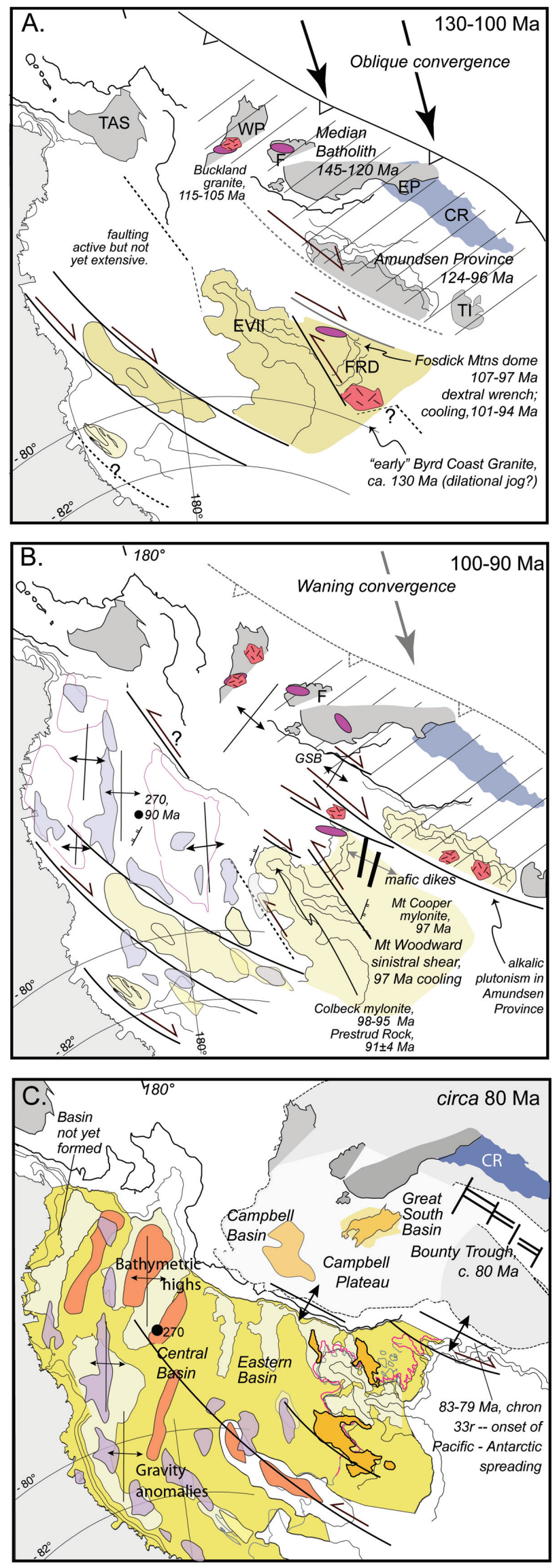

FIGURE 9 Development of the WARS in three hypothesized stages, based on the observations of strain accommodated upon wrench and extensional fault systems in Marie Byrd Land, a part of the WARS that resides above sea level. Basement graben configuration based on Cooper et al. (1991b) and Trey et al. (1997).

(A) $130 \mathrm{Ma}$ to $100 \mathrm{Ma}$, interpreted configuration of the East Gondwana margin. HT metamorphism and crustal melting (ellipse symbol) is contemporaneous with arc magmatism at inboard sites including Fiordland (F); Paparoa complex in Western Province, NZ (WP); and Fosdick Mountains gneiss dome in MBL. Diachroneity of calcalkaline plutonism in the Median Batholith and Amundsen province may be a reflection of subducted slab geometry or the configuration of the Phoenix-Pacific spreading ridge offshore (Figures 3 and 5). Sites of alkalic magmatism may be an expression of dilational jogs in wrench zones or within detachment structures. TAS = Tasmania; EP = Eastern Province, NZ; CR = Chatham Rise; $\mathrm{TI}=$ Thurston Island.

(B) 100-90 Ma, major phase of intracontinental deformation in the WARS. Tensile dike arrays and alkalic plutons were emplaced across the back-arc region. Blue shaded areas are gravity anomalies corresponding with high-density material along basin axes (Cooper et al., 1991b). Differential movement upon steep wrench zones is recorded by ${ }^{40} \mathrm{Ar} /{ }^{39} \mathrm{Ar}$ and AFT data that record rapid cooling between $97 \mathrm{Ma}$ and $90 \mathrm{Ma}$ for fault zone samples (Table 1). Based on the available data there appears to be an age progression from northeast toward southwest, with site DSDP 270 in the Ross Sea recording the youngest of the older subset of cooling ages, if the dominant population is accepted as the AFT cooling age (Fitzgerald and Baldwin, 1997). Dominant wrench deformation is documented in Marie Byrd Land, and prevalent normal faulting is inferred in the Ross Sea. The regional strain variation may be due to contrasts in competency of the pre-Mesozoic continental lithosphere, contrasting thermal conditions arising from lithospheric thinning or the dynamics of the convergent plate boundary (e.g., Figure 8), or the transition from a region undergoing oblique subduction of young continental lithosphere (eastern WARS) to one experiencing slow rifting between mature continental crust of Antarctica-Australia (western WARS).

(C) Ca. $80 \mathrm{Ma}$, the time of breakup between WANT and NZCampbell Plateau. Continental extension across the WARS and Campbell Plateau exceeded 100 percent and was completed prior to onset of seafloor spreading. Blue shaded areas are gravity anomalies corresponding with high-density material along basin axes; red areas are bathymetric (and basement) highs (Cooper et al., 1991b). Extension direction for breakup was nearly orthogonal to that for WARS opening and the rifted margin cuts at a high angle across Ross Sea basins (Lawver and Gahagan, 1994). It is probable that a preexisting wrench fault structure was reactivated at the time of breakup. This would explain the exceptionally abrupt ocean-continent boundary along the coast of Marie Byrd Land (Gohl, 2008, this volume). 
upon structurally controlled pathways, is being addressed by isotopic and geochemical investigation. A petrogenetic link between Ford Granodiorite (source) and Byrd Coast granite (product) has been demonstrated in the region (Weaver et al., 1991; Pankhurst et al., 1998). New Nd isotope data from the Fosdick Mountains strengthen this interpretation (Saito et al., 2007). Therefore it is plausible that regional melting of Ford Granodiorite contributed to anatectic granite magmas that were capable of vertical or lateral migration during oblique convergence (Weaver et al., 1995) to transtension (Siddoway et al., 2005) along the Early Cretaceous plate margin.

HT metamorphism and exhumation of deep crustal rocks on detachment structures are documented over a wide region proximal to the Gondwana margin arc in New Zealand and MBL (Kimbrough and Tulloch, 1989; Fitzgerald and Baldwin, 1997; Forster and Lister, 2003; Siddoway et al., 2004b; Kula et al., 2007), suggesting pervasive middle to lower crustal flow and advection of magmatic heat (Ehlers, 2005) over a large region (Figures 8 and 9). The existing geochronological and thermochronological data reviewed above suggest a comparatively short and dynamic development of the Fosdick gneiss dome and other strike slip shear zones active in the eastern WARS in Cretaceous time. U-Pb SHRIMP zircon data indicate that HT metamorphism was in effect by $140 \mathrm{Ma}$ and growth of new igneous zircon within the anatectic granites was under way by $115 \mathrm{Ma}$ (Figure 6) (Siddoway et al., 2006); a possible indication that crustal melting and conditions favorable for viscous flow arose during convergent tectonism and crustal thickening along the East Gondwana active margin.

In the Fosdick Mountains gneiss dome syn- to posttectonic granite intrusions of $107 \mathrm{Ma}$ to $96 \mathrm{Ma}$ age delimit the duration of detachment tectonics and exhumation, with upward translation through ductile to brittle conditions and development of a mylonitic shear zone at the transition (McFadden et al., 2007). Following the emplacement of the dome, mid-crustal magmatism and flow ceased and dome rocks cooled rapidly from $>700^{\circ} \mathrm{C}$ to $<200^{\circ} \mathrm{C}$ at rates as high as $70^{\circ} \mathrm{C} / \mathrm{m}$.y. (Richard et al., 1994). Overprinting textures of cordierite possibly record decompression of footwall rocks due to translation upon the detachment structure; and the late-tectonic melt-filled, normal-sense shear bands that cut all older structures may be an indication of a small volume of late leucogranite formed by decompression-induced melting (Siddoway et al., 2004b; Korhonen et al., 2007b). The very high rates of cooling recorded by ${ }^{40} \mathrm{Ar} /{ }^{39} \mathrm{Ar}$ mineral cooling data are comparable to rates of advective heat loss that arise from pluton emplacement in cold country rock (Fayon et al., 2004). These observations are possible indications of a component of upward, gravity-driven flow (diapirism) during emplacement of the dome (e.g., Teyssier and Whitney, 2002). The association of the Fosdick Mountains gneiss dome with the Balchen Glacier fault, which is known to be an inherited Paleozoic structure (Richard et al., 1994; Siddoway et al., 2004b), suggests that a crustal to lithospheric-scale discontinuity has a role in gneiss dome emplacement.

The predominance of subhorizontal fabrics (rather than vertical geometry expected for strike slip faults in the brittle upper crust) is considered to be either (1) an expression of coupling between crustal layers of contrasting compentency (e.g., metatexite versus diatexite plus leucogranite) that accommodates strain by different mechanisms (e.g., Tikoff et al., 2002), or (2) accentuation of vertical shortening at the "melt propagation front" for melt-rich diatexite-leucogranite as melt-rich material migrated upward and was arrested at the thermal or permeability boundary (e.g., Sawyer, 2001) represented by metatexite (Figure 8) or (3) a change in orientation of the shortening axis of strain due to unroofing, to coincide with direction of gravitational load.

\section{Overview of the West Antarctic Rift System}

Structural and geochronological data from sites throughout the eastern WARS show a broad compatibility with respect to ENE coordinates for principal finite strain and timing of crustal thinning deformation at ca. 105-95 Ma. The kinematic compatibility between structures of the brittle upper and viscous lower crust is a great aid to interpretation of the mechanisms of formation of the WARS. The best-exposed, crustal-scale structure with lateral extent in Marie Byrd Land is the South Fosdick detachment fault, which accommodated dextral normal oblique translation of a pervasively brittlely deformed hanging wall block to the SW and WSW kinematic sense (dip dependent) along a mean direction of $240^{\circ}$ (McFadden et al., 2007). The transport direction agrees with stretching axes at deeper levels within the Fosdick dome, determined to be 060-240 to 070-250 (Siddoway et al., 2004b).

Structural data that support an ENE direction for the maximum principle finite strain axis for the Ford Ranges (Figure 4) include the regional mafic dike array (Siddoway et al., 2005); mapped and inferred NW-SE dip-slip normal faults in the southern Ford Ranges; and brittle kinematic criteria on ESE-striking dextral oblique minor faults and on NEstriking sinistral shear fractures. Among mesoscopic brittle structures on land, strike slip faults are prevalent, forming populations that accommodated both dextral and sinistral motion (Figure 4). Mutually crosscutting relationships with alkalic dikes indicate that the strike slip faults were active during the 070-250-directed opening that is recorded by the mafic dike array. Regional mapping indicates that Byrd Coast plutons are spatially associated with inferred major faults and may occupy releasing bends (Figures 4 and 9).

Consequently, the dextral and sinistral regional-scale faults in western Marie Byrd Land are viewed as contemporaneous conjugate structures whose motion aided ENEWSW dextral transtension in the eastern WARS (Figure 4). Kinematics of normal faults mapped offshore of Edward VII Peninsula (Luyendyk et al., 2001) are consistent, as is 
the direction of margin-parallel divergence across a shortlived MBL-Bellingshausen plate boundary further east (Heinemann et al., 1999). The stretching direction for the eastern WARS in MBL is generally parallel to that predicted from the orientation and geometry of basement grabens in the Ross Sea (Cooper et al., 1991a, 1997; Davey and Brancolini, 1995; Trey et al., 1997). The documentation of important wrench deformation in MBL supports past interpretations of wrench and transfer faults within the WARS (e.g., Grindley and Davey, 1982) and for the first time determines their orientation and kinematics.

The apparent change from prevalent normal faults in the Ross Sea portion of the rift (Cooper et al., 1991a,b; Tessensohn and Wörner, 1991) to dextral strike slip in the eastern WARS implies a rotation of principal stress axes from $\sigma_{1}$ vertical in the west to $\sigma_{2}$ vertical in the east. The spatial variation in kinematics and dynamics across the WARS probably is related to the geometry of subducted lithosphere at the active margin (e.g., Bradshaw, 1989; Luyendyk, 1995), or is an expression of a regional strain gradient between the East Gondwana convergent boundary and the AustraliaAntarctica boundary, undergoing slow divergence since ca. $125 \mathrm{Ma}$ (Cande and Mutter, 1982; Tessensohn and Wörner, 1991).

The conjugate wrench zones active in MBL between $107 \mathrm{Ma}$ and $97 \mathrm{Ma}$ indicate a vertical orientation for the intermediate axis of principle finite strain, with axis of minimum finite strain oriented NW-SE in the plane of the earth. Transcurrent strain in MBL is consistent with the oblique convergence vector (Figures 9a and 9b) determined for Late Cretaceous time (Vaughan and Storey, 2000; Sutherland and Hollis, 2001; Vaughan et al., 2002a). Therefore, the postulated tectonic boundary separating the Ross continental province from the Amundsen arc province (Pankhurst et al., 1998) probably corresponds to an intracontinental dextral transform fault. The Amundsen province boundary is inferred on paleomagnetic grounds to have an approximately E-W trend in Marie Byrd Land (Figure 9b) (DiVenere et al., 1996). Restoration of dextral motion across an E-W transform fault potentially would place the Amundsen province magmatic arc outboard of the Ford Ranges (Figure 9a). Such a reconstruction helps explain the extent and degree of regional heating throughout the Ross province that elevated crustal isotherms (Figure 5b and 5c), induced extensive mid-crustal flow of the type documented in the Fosdick Mountains (Figure 8c), promoted rapid intracontinental extension across the WARS, and prevented development of orogenic topography. Dynamic subduction (e.g., Giunchi et al., 1996) or a postulated mantle plume (Weaver et al., 1994; Storey et al., 1999) may have been responsible for preventing dramatic subsidence and voluminous infilling of sedimentary basins of the Ross Sea (Wilson et al., 1998; Luyendyk et al., 2001; Karner et al., 2005).

\section{CONCLUSIONS}

The determination of dextral transtensional strain in the eastern WARS in Marie Byrd Land is consistent with the current picture of tectonic plate interactions at the PhoenixEast Gondwana (Pacific sector) boundary, with the final stages of subduction marked by oblique convergence of young oceanic crust (Bradshaw, 1989; Luyendyk et al., 1995; Sutherland and Hollis, 2001; Wandres and Bradshaw, 2005), as far east as Palmer Land (Figure 3) (Vaughan and Storey, 2000; Vaughan et al., 2002b). It is now clear that strike slip fault systems, thought to be in existence during oblique convergence at the Early Cretaceous margin (Weaver et al., 1995), remained active and accommodated intracontinental extension in the WARS until ca. $90 \mathrm{Ma}$. The structural and thermochronology record from MBL and the eastern Ross Sea indicates that the intracontinental extension between EANT and WANT that brought about opening the WARS by $90 \mathrm{Ma}$ is distinct from the NZ-WANT breakup at $83 \mathrm{Ma}$ and later. There is compelling evidence that the sharp continentocean boundary that distinguishes the MBL margin from the other gradational continent boundaries of the Antarctic Plate (Gohl, 2008, this volume) is controlled by a wrench zone formed during opening of the WARS.

It may be that relict subvertical transcurrent zones penetrating to the base of the crust provide a deep-seated conduit for magmatism in the linear volcanic mountain ranges of the MBL volcanic province (LeMasurier and Rex, 1989), or control the deep narrow lineaments in the subglacial topography beneath the Pine Island and Thwaites ice streams, $950 \mathrm{~km}$ to the east (Holt et al., 2006; Vaughan et al., 2006). In this way the lithospheric-scale structures formed during development of the West Antarctic rift system continue to exert fundamental influences on the long-term continental evolution of West Antarctica.

\section{ACKNOWLEDGMENTS}

Sincere thanks are extended to J. D. Bradshaw, F. J. Davey, and F. Tessensohn who provided reviews; to A. K. Cooper for his dedicated service as editor; and to the ISAES 2007 program committee for inviting this contribution. M. Brown and $\mathrm{N}$. Mortimer provided input on a prior manuscript. Interpretations represented here have arisen through collaborations with B. P. Luyendyk, C. M. Fanning, R. McFadden, C. Teyssier, D. L. Whitney, C. A. Ricci, D. Wilson, F. J. Korhonen, and S. Saito. Other contributors include the Support Office for Aerogeophysical Research (SOAR) (1998), A. Whitehead, L. Sass III, S. Kruckenberg, J. Haywood, S. Fadrhonc, and M. Siddoway. Mike Roberts (polar guide), Raytheon Polar Services, the 109th Air National Guard, and Kenn Borek Air provided logistical support over several years. Warm thanks are also due to GANOVEX VII (1992-1993); Spedizione X, Italiantartide (1996-1997); J. Müller; and members of 
the South Pacific Rim Tectonics Expedition (SPRITE). S. Borg and J. Palais are thanked for program leadership. The U.S. National Science Foundation provided support through grants OPP-0338279, 0443543, 9702161, and 9615282. The content of the article is the work of the author and does not necessarily reflect the views of the National Science Foundation. Colorado College faculty research awards provided further support.

\section{REFERENCES}

Adams, C. J. 1986. Geochronological studies of the Swanson Formation of Marie Byrd Land, West Antarctica, and correlation with northern Victoria Land, East Antarctica and the South Island, New Zealand. New Zealand Journal of Geology and Geophysics 29:345-358.

Adams, C. J. 1987. Geochronology of granite terranes in the Ford Ranges, Marie Byrd Land, West Antarctica. New Zealand Journal of Geology and Geophysics 30:51-72.

Adams, C. J. 2004. Rb-Sr age and strontium isotopic characteristics of the Greenland Group, Buller terrane, New Zealand, and correlations at the East Gondwana margin. New Zealand Journal of Geology and Geophysics 47:189-200.

Adams, C. J., D. Seward, and S. D. Weaver. 1995. Geochronology of Cretaceous granites and metasedimentary basement on Edward VII Peninsula, Marie Byrd Land, West Antarctica. Antarctic Science 7:265-277.

Adams, C. J., R. J. Pankhurst, R. Maas, and I. L. Millar. 2005. Nd and Sr isotopic signatures of metasedimentary rocks around the South Pacific margin and implications for their provenance. Geological Society of London Special Publication 246:113-141.

Behrendt, J. C. 1999. Crustal and lithospheric structure of the West Antarctic Rift System from geophysical investigations-a review. Global and Planetary Change 23:25-44.

Behrendt, J. C., W. E. LeMasurier, A. K., Cooper, F., Tessensohn, A. Trehu, and D. Damaske. 1991. Geophysical Studies of the West Antarctic Rift System. Tectonics 10:1257-1273.

Behrendt, J. C., D. D. Blankenship, C. A. Finn, R. E. Bell, R. E. Sweeney, S. M. Hodge, and J. M. Brozena. 1994. Casertz aeromagnetic data reveal Late Cenozoic flood basalts (?) in the West Antarctic Rift System. Geology 22:527-530.

Behrendt, J. C., R. Saltus, D. Damaske, A. McCafferty, C. A. Finn, D. Blankenship, and R. E. Bell. 1996. Patterns of late Cenozoic volcanic and tectonic activity in the West Antarctic rift system revealed by aeromagnetic surveys. Tectonics 15:660-676.

Bell, R. E., D. D. Blankenship, C. A. Finn, D. L. Morse, T. A. Scambos, J. M. Brozena, and S. M. Hodge. 1998. Influence of subglacial geology on the onset of a West Antarctic ice stream from aerogeophysical observations. Nature 394:58-62.

Bialas, R. W., W. R. Buck, M. Studinger, and P. G. Fitzgerald. 2007. Plateau collapse model for the Transantarctic Mountains-West Antarctic Rift System: Insights from numerical experiments. Geology 35:687-690.

Blumenfeld, P., and J.-L. Bouchez. 1988. Shear criteria in granite and migmatite deformed in the magmatic and solid state. Journal of Structural Geology 10:361-372.

Bradshaw, J. D. 1989. Cretaceous geotectonic patterns in the New Zealand region. Tectonics 8:803-820.

Bradshaw, J. D. 2007. The Ross Orogen and Lachlan Fold Belt in Marie Byrd Land, Northern Victoria Land and New Zealand: Implication for the tectonic setting of the Lachlan Fold Belt. In Antarctica: A Keystone in a Changing World-Online Proceedings for the Tenth International Symposium on Antarctic Earth Sciences, eds. Cooper, A. K., C. R. Raymond et al., USGS Open-File Report 2007-1047. Short Research Paper 059, doi:10.3133/of2007-1047.srp059.
Bradshaw, J. D., B. Andrew, and B. D. Field. 1983. Swanson Formation and related rocks of Marie Byrd Land and a comparison with the Robertson Bay Group of northern Victoria Land. In Antarctic Earth Science, eds. R. L. Oliver, P. R. James, J. B. Jago, pp. 274-279. Canberra: Australian Academy of Science.

Bradshaw, J. D., R. J. Pankhurst, S. D. Weaver, B. C. Storey, R. J. Muir, and T. R. Ireland. 1997. New Zealand superterranes recognized in Marie Byrd Land and Thurston Island. In The Antarctic Region, Geological Evolution and Processes, ed. C. A. Ricci, pp. 429-436. Siena: Terra Antartica Publication.

Brown, M. 1973. The definition of metatexis, diatexis, and migmatite. Proceedings of the Geologists' Association 84:371-382.

Brown, M. 2007. Crustal melting and melt extraction, ascent and emplacement in orogens: Mechanisms and consequences. Journal of the Geological Society of London 164:709-730.

Brown, M., and R. A. Pressley. 1999. Crustal melting in nature: Prosecuting source processes. Physics and Chemistry of the Earth, Part A: Solid Earth and Geodesy 24:305-316.

Cande, S. C., and J. C. Mutter. 1982. A revised identification of the oldest sea-floor spreading anomalies between Australia and New Zealand. Earth and Planetary Science Letters 58(2):151-160.

Cape Roberts Science Team. 2000. Studies from the Cape Roberts Project; Ross Sea, Antarctica, Initial Report on CRP-3. Terra Antartica 7(1-2):185-209.

Collins, W. J. 2002a. Nature of extensional accretionary orogens. Tectonics 21(4), doi:10.1029/2000TC001272.

Collins, W. J. 2002b. Hot orogens, tectonic switching, and creation of continental crust. Geology 30(6): 535-538.

Collins, W. J., and B. E. Hobbs. 2001. What caused the Early Silurian change from mafic to silicic (S-type) magmatism in the eastern Lachlan Fold Belt? Australian Journal of Earth Sciences 48:25-41.

Cook, R. A., R. Sutherland, and H. Zhu. 1999. Cretaceous-Cenozoic Geology and Petroleum Systems of the Great South Basin, New Zealand. Lower Hutt, New Zealand: Institute of Geological and Nuclear Sciences.

Cooper, A. K., and F. J. Davey. 1985. Episodic rifting of Phanerozoic rocks in the Victoria Land Basin, western Ross Sea, Antarctica. Science 229:1085-1087.

Cooper, A. K., F. J. Davey, and J. C. Behrendt. 1991a. Structural and depositional controls on Cenozoic and (?)Mesozoic strata beneath the western Ross Sea. In Geological Evolution of Antarctica, eds. M. R. A. Thomson, J. A. Crame, J. W. Thomson, pp. 279-283. Cambridge: Cambridge University Press International.

Cooper, A. K., F. J. Davey, and K. Hinz. 1991b. Crustal extension and origin of sedimentary basins beneath the Ross Sea and Ross Ice Shelf, Antarctica. In Geological Evolution of Antarctica, eds. M. R. A. Thomson, J. A. Crame, and J. W. Thomson, pp. 285-291. Cambridge: Cambridge University Press.

Cooper, A. K., H. Trey, G. Pellis, G. Cochrane, F. Egloff, M. Busetti, and ACRUP Working Group. 1997. Crustal structure of the Southern Central Trough, Western Ross Sea. In The Antarctic Region: Geological Evolution and Processes, ed. C. A. Ricci, pp. 637-642. Siena: Terra Antartica Publication.

Cooper, R. A., and A. Tulloch. 1992. Early Paleozoic terranes in New Zealand and their relationship to the Lachlan Fold Belt. Tectonophysics 214:129-144.

Dalziel, I. W. D. 1997. Neoproterozoic-Paleozoic geography and tectonics: Review, hypothesis, environmental speculation. Geological Society of America Bulletin 109:16-42.

Dalziel, I. W. D., B. C. Storey, S. W. Garrett, A. M. Grunow, L. D. B. Herrod, and R. J. Pankhurst. 1987. Extensional tectonics and the fragmentation of Gondwanaland. In Continental Extensional Tectonics, eds. M. P. Coward, J. F. Dewey, and P. L. Hancock, Geological Society Special Publication 28:433-441. 
Danesi, S., and A. Morelli. 2001. Structure of the upper mantle under the Antarctic Plate from surface wave tomography. Geophysical Research Letters 28:4395-4398.

Davey, F. J., and G. Brancolini. 1995. The Late Mesozoic and Cenozoic structural setting of the Ross Sea region. In Geology and Seismic Stratigraphy of the Antarctic Margin, eds. A. K. Cooper, P. F. Barker, and G. Brancolini, Antarctic Research Series 68:167-182. Washington, D.C.: American Geophysical Union.

Davey, F. J., and L. De Santis. 2006. A multi-phase rifting model for the Victoria Land Basin, western Ross Sea, in Antarctica, Contributions to Global Earth Sciences, eds. D. K. Fütterer, D. Damaske, G. Kleinschmidt, H. Miller, and F. Tessensohn, pp. 303-308. Berlin: Springer.

Decesari, R. C., C. C. Sorlien, B. P. Luyendyk, L. R. Bartek, J. B. Diebold, and D. S. Wilson. 2003. Tectonic evolution of the Coulman High and Central Trough along the Ross Ice Shelf, Southwestern Ross Sea, Antarctica. Eos Transactions American Geophysical Union, Fall Meeting Supplement, Abstract T12A-0447.

DiVenere, J., D. V. Kent, and I. W. D. Dalziel. 1996. Summary of palaeomagnetic results from West Antarctica; implications for the tectonic evolution of the Pacific margin of Gondwana during the Mesozoic. In Weddell Sea Tectonics and Gondwana Break-up, eds. B. C. Storey, E. C. King and R. A. Livermore, Geological Society Special Publication 108:31-43.

Eagles, G., K. Gohl, and R. D. Larter. 2004. High-resolution animated tectonic reconstruction of the South Pacific and West Antarctic Margin. Geochemistry Geophysics Geosystems 5:Q07002, doi:10.1029/2003GC000657.

Ehlers, T. A. 2005. Crustal thermal processes and the interpretation of thermochronometer data. Reviews in Mineralogy and Geochemistry 58:315-350.

Elliot, D. H., and T. H. Fleming. 2004. Occurrence and dispersal of magmas in the Jurassic Ferrar large igneous province, Antarctica. Gondwana Research 7(1):223-237.

Elliot, D. H., T. H. Fleming, P. Kyle, and K. A. Foland. 1999. Long-distance transport of magmas in the Jurassic Ferrar large igneous province, Antarctica. Earth and Planetary Science Letters 167:89-104.

Fayon, A. K., D. L. Whitney, and C. Teyssier. 2004. Exhumation of orogenic crust: Diapiric ascent versus low-angle normal faulting. In Gneiss Domes in Orogeny, eds. D. L. Whitney, C. Teyssier, and C. S. Siddoway, Geological Society of America Special Paper 380:129-139.

Fergusson, C. L., and J. Coney. 1992. Implications of a Bengal fan-type deposit in the Paleozoic Lachlan fold belt of southeastern Australia. Geology 20:1047-1049.

Fergusson, C. L., R. A. Henderson, I. Withnall, C. M. Fanning, D. Phillips, and K. Lewthwaite. 2007. Structural, metamorphic, and geochronological constraints on alternating compression and extension in the Early Paleozoic Gondwanan Pacific margin, northeastern Australia. Tectonics 26(3):TC300.

Ferraccioli, F., E. Bozzo, and D. Damaske. 2002. Aeromagnetic signatures over western Marie Byrd Land provide insight into magmatic arc basement, mafic magmatism and structure of the eastern Ross Sea rift flank. Tectonophysics 347:139-165.

Finn, C. A., R. D. Müller, and K. S. Panter. 2005. A Cenozoic diffuse alkaline magmatic province (DAMP) in the southwest Pacific without rift or plume origin. Geochemistry Geophysics Geosystems 6, doi:10.1029/2004GC000723.

Fitzgerald, P. G. 2002. Tectonics and landscape evolution of the Antarctic plate since the breakup of Gondwana, with an emphasis on the West Antarctic Rift System and the Transantarctic Mountains. In Antarctica at the Close of a Millennium, eds. J. A. Gamble, D. N. B. Skinner, and S. Henry, pp. 453-469. Wellington: Royal Society of New Zealand.

Fitzgerald, P. G., and S. L. Baldwin. 1997. Detachment fault model for the evolution of the Ross Embayment. In The Antarctic Region: Geological Evolution and Processes, ed. C. A. Ricci, pp. 555-564. Siena: Terra Antartica Publication.
Fitzgerald, P. G., M. Sandiford, P. J. Barrett, and A. J. W. Gleadow. 1986. Asymmetric extension associated with uplift and subsidence in the Transantarctic Mountains and Ross Embayment. Earth and Planetary Science Letters 81:67-78.

Ford, A. B., and P. J. Barrett. 1975. Basement rocks of the south-central Ross Sea, Site 270, DSDP Leg 28. In Initial Reports of the Deep Sea Drilling Project, eds. D. E. Hayes, I. A. Frakes et al. Washington, D.C.: U.S. Government Printing Office, doi:10.2973/dsdp.proc.28.131.1975.

Forster, M. A., and G. S. Lister. 2003. Cretaceous metamorphic core complexes in the Otago Schist, New Zealand. Australian Journal of Earth Sciences 50:181-198.

Foster, D. A., D. R. Gray, and Bucher, M. 1999. Chronology of deformation within the turbidite-dominated Lachlan orogen: Implications for the tectonic evolution of eastern Australia and Gondwana. Tectonics 18, doi:10.1029/1998TC900031.

Gaffney, A. M., and C. S. Siddoway. 2007. Heterogeneous sources for Pleistocene lavas of Marie Byrd Land, Antarctica: New Data from the SW Pacific Diffuse Alkaline Magmatic Province. In Antarctica: A Keystone in a Changing World-Online Proceedings for the Tenth International Symposium on Antarctic Earth Sciences, eds. Cooper, A. K., C. R. Raymond et al., USGS Open-File Report 2007-1047, Extended abstract 063, http://pubs.usgs.gov/of/2007/1047/.

Gaina, C., R. D. Müller, J.-Y. Royer, J. Stock, J. Hardebeck, and A. Symonds. 1998. The tectonic history of the Tasman Sea: A puzzle with 13 pieces. Journal of Geophysical Research 103:12413-12433.

Gibson, G. M., and T. R. Ireland. 1995. Granulite formation during continental extension in Fiordland, New Zealand. Nature 375:479-482.

Gibson, G. M., and T. R. Ireland. 1996. Extension of Delamerian (Ross) Orogen into western New Zealand; evidence from zircon ages and implications for crustal growth along the Pacific margin of Gondwana. Geology 24:1087-1090.

Gibson, G. M., I. McDougall, and T. R. Ireland. 1988. Age constraints on metamorphism and the development of a metamorphic core complex in Fiordland, southern New Zealand. Geology 16:405-408.

Giunchi, C., R. Sabadini, E. Boschi, and P. Gasperini. 1996. Dynamic models of subduction-Geophysical and geological evidence in the Tyrrhenian Sea. Geophysical Journal International 126:555-578.

Glen, R. A. 2005. The Tasmanides of eastern Australia. In Terrane Processes at the Margin of Gondwana, eds. A. Vaughan, P. Leat, and R. J. Pankhurst, Geological Society of London Special Publication 246:23-96.

Gohl, K. 2008, this volume. Antarctica's continent-ocean boundaries: Consequences for tectonic reconstructions. In Antarctica: A Keystone in a Changing World, eds. A. K. Cooper et al. Washington, D.C.: The National Academies Press.

Gray, D. R., and D. A. Foster. 2004. Tectonic evolution of the Lachlan Orogen, southeast Australia: Historical review, data synthesis and modern perspectives. Australian Journal of Earth Sciences 51(6):773-817.

Grindley, G. W., and F. J. Davey. 1982. The reconstruction of New Zealand, Australia and Antarctica. In Antarctic Geoscience, ed. C. Craddock, pp. 15-26. Madison: University of Wisconsin Press.

Grunow, A. M., D. V. Kent, and I. W. D. Dalziel. 1991. New paleomagnetic data from Thurston Island: Implications for the tectonics of West Antarctica and Weddell Sea opening. Journal of Geophysical Research 96:17935-17954.

Hamilton, R. J., C. C. Sorlien, B. P. Luyendyk, L. R. Bartek, and S. A. Henrys. 1998. Tectonic regimes and structural trends off Cape Roberts, Antarctica. Terra Antartica 5(3):261-272.

Hayes, D. E., and F. J. Davey. 1975. A geophysical study of the Ross Sea, Antarctica. In Initial Reports of the Deep Sea Drilling Project, eds. D. E. Hayes, L. A. Frakes et al. Washington, D.C.: U.S. Government Printing Office, doi:10.2973/dsdp.proc.28.134.1975

Heinemann, J., J. Stock, K. Clayton, S. Hafner, S. Cande, and C. Raymond. 1999. Constraints on the proposed Marie Byrd Land-Bellingshausen plate boundary from seismic reflection data. Journal of Geophysical Research 104:25321-25330. 
Hoernle, K., F. Hauff, R. Werner, N. Mortimer, P. van den Bogaard, J. Geldmacher, and D. Garbe-Schoenberg. 2004. New insights into the origin and evolution of the Hikurangi oceanic plateau. Eos Transactions of the American Geophysical Union 85:401-406, doi:10.1029/2004EO410001.

Hollis, J. A., G. L. Clarke, K. A. Klepeis, N. R. Daczko, and T. R. Ireland. 2004. The regional significance of Cretaceous magmatism and metamorphism in Fiordland, New Zealand, from U-Pb zircon geochronology. Journal of Metamorphic Geology 22:607-627.

Holt, J. W., D. D. Blankenship, D. L. Morse, D. A. Young, M. E. Peters, S. D. Kempf, T. G. Richter, D. G. Vaughan, and H. F. J. Corr. 2006. New boundary conditions for the West Antarctic Ice Sheet: Subglacial topography of the Thwaites and Smith glacier catchments. Geophysical Research Letters 33:L09502, doi:10.1029/2005GL025561.

Huerta, A. 2007. Byrd drainage system: Evidence of a Mesozoic West Antarctic Plateau. In Antarctica: A Keystone in a Changing World-Online Proceedings for the Tenth International Symposium on Antarctic Earth Sciences, eds. Cooper, A. K., C. R. Raymond et al., USGS Open-File Report 2007-1047, Extended Abstract 091, http://pubs.usgs. gov/of/2007/1047/.

Ireland, T. R., and G. M. Gibson. 1998. SHRIMP monazite and zircon geochronology of high-grade metamorphism in New Zealand. Journal of Metamorphic Geology 16:149-167.

Jokat, W., T. Boebel, M. König, and M. Uwe. 2003. Timing and geometry of early Gondwana breakup. Journal of Geophysical Research 108:2428.

Karner, G. D., M. Studinger, and R. E. Bell. 2005. Gravity anomalies of sedimentary basins and their mechanical implications: Application to the Ross Sea basins, West Antarctica. Earth and Planetary Science Letters 235:577-596.

Kimbrough, D., and A. J. Tulloch. 1989. Early Cretaceous age of orthogneiss from the Charleston Metamorphic Group, New Zealand. Earth and Planetary Science Letters 95:130-140.

Korhonen, F. J., M. Brown, and C. S. Siddoway. 2007a. Petrologic and geochronological constraints on the polymetamorphic evolution of the Fosdick Migmatite Dome, Marie Byrd Land, West Antarctica. In Antarctica: A Keystone in a Changing World-Online Proceedings for the Tenth International Symposium on Antarctic Earth Sciences, eds. Cooper, A. K., C. R. Raymond et al., USGS Open-File Report $2007-$ 1047, Extended abstract 049, http://pubs.usgs.gov/of/2007/1047/.

Korhonen, F. J., M. Brown, and C. S. Siddoway. 2007b. Unraveling polyphase high-grade metamorphism and anatexis in the Fosdick migmatite dome, West Antarctica, using mineral equilibria modeling and in situ monazite geochronology. Eos Transactions of American Geophysical Union, Fall Meeting Supplement 88, Abstract V04-4536.

Kula, J., A. J. Tulloch, T. L. Spell, and M. L. Wells. 2007. Two-stage rifting of Zealandia-Australia-Antarctica: Evidence from ${ }^{40} \mathrm{Ar} /{ }^{39} \mathrm{Ar}$ thermochronometry of the Sisters shear zone, Stewart Island, New Zealand. Geology 35:411-414, doi:10.1130/G23432A.1.

Laird, M. G., and J. D. Bradshaw. 2004. The break-up of a long-term relationship: The Cretaceous separation of New Zealand from Gondwana. Gondwana Research 7:273-286.

Larter, R. D., A. P. Cunningham, F. Barker, K. Gohl, and F. O. Nitsche. 2002. Tectonic evolution of the Pacific margin of Antarctica. 1. Late Cretaceous tectonic reconstructions. Journal of Geophysical Research 107:2345.

Lawrence, J. F., D. A. Wiens, A. A. Nyblade, S. Anandakrishnan, J. Shore, and D. Voigt. 2006. Upper mantle thermal variations beneath the Transantarctic Mountains inferred from teleseismic S-wave attenuation. Geophysical Research Letters 33:L03303, doi:10.1029/2005GL024516.

Lawver, L. A., and L. M. Gahagan. 1994. Constraints on the timing of extension in the Ross Sea region. Terra Antartica 1:545-552.

LeMasurier, W. E., and C. A. Landis. 1996. Mantle-plume activity recorded by low relief erosion surfaces in West Antarctica and New Zealand. Bulletin of the Geological Society of America 108:1450-1466.
LeMasurier, W. E. 2008. Neogene extension and basin deepening in the West Antarctic rift inferred from comparisons with the East African rift and other analogs. Geology 36(3):247-250, doi:10.1130/G24363A.1.

LeMasurier, W. E., and D. C. Rex. 1989. Evolution of linear volcanic ranges in Marie Byrd Land, West Antarctica. Journal of Geophysical Research, B 94:7223-7236.

Li, Z. X., and C. M. Powell. 2001. An outline of the palaeogeographic evolution of the Australasian region since the beginning of the Neoproterozoic. Earth-Science Reviews 53.

Lisker, F., and M. Olesch. 1998. Cooling and denudation history of western Marie Byrd Land, Antarctica, based on apatite fission-tracks. In Advances in Fission-Track Geochronology, eds. P. Van den haute and F. De Corte, pp. 225-240. Dordrecht: Kluwer Academic Publishers.

Lister, G. S., M. Etheridge, and P. Symonds. 1991. Detachment models for the formation of passive continental margins. Tectonics 10:1038-1064.

Lowe, A. L., and J. B. Anderson. 2002. Reconstruction of the West Antarctic ice sheet in Pine Island Bay during the Last Glacial Maximum and its subsequent retreat history. Quaternary Science Reviews 21:1879-1897.

Luyendyk, B. 1995. Hypothesis for Cretaceous rifting of East Gondwana caused by subducted slab capture. Geology 23:373-376.

Luyendyk, B. P., C. H. Smith, and F. M. van der Wateren. 1994. Glaciation, block faulting, and volcanism in western Marie Byrd Land. Terra Antartica 1:541-543.

Luyendyk, B., S. Cisowski, C. H. Smith, S. Richard, and D. Kimbrough. 1996. Paleomagnetic study of the northern Ford Ranges, western Marie Byrd Land, West Antarctica: Motion between West and East Antarctica. Tectonics 15:122-141.

Luyendyk, B. P., C. C. Sorlien, D. S. Wilson, L. R. Bartek, and C. S. Siddoway. 2001. Structural and tectonic evolution of the Ross Sea Rift in the Cape Colbeck region, eastern Ross Sea, Antarctica. Tectonics 20:933-958.

Luyendyk, B. P., D. S. Wilson, and C. S. Siddoway. 2003. The eastern margin of the Ross Sea Rift in western Marie Byrd Land: Crustal structure and tectonic development. Geochemistry Geophysics Geosystems, doi:10.1029/2002GC000462.

Marrett, R., and R. W. Allmendinger. 1990. Kinematic analysis of fault-slip data. Journal of Structural Geology 12:973-986.

Maule, C. F., M. E. Purucker, N. Olsen, and K. Mosegaard. 2005. Heat flux anomalies in Antarctica revealed by satellite magnetic data. Science 309:464-467.

McAdoo, D., and S. Laxon. 1997. Antarctic tectonics: Constraints from an ERS-1 satellite marine gravity field. Science 276:556-561.

McFadden, R., C. S. Siddoway, C. Teyssier, C. M. Fanning, and S. C. Kruckenberg. 2007. Cretaceous oblique detachment tectonics in the Fosdick Mountains, Marie Byrd Land, Antarctica. In Antarctica: A Keystone in a Changing World-Online Proceedings for the Tenth International Symposium on Antarctic Earth Sciences, eds. Cooper, A. K., C. R. Raymond et al., USGS Open-File Report 2007-1047. Short Research Paper 046, doi:10.3133/of2007-1047.srp046.

McKenzie, D., and K. Priestley. 2007. The influence of lithospheric thickness variations on continental evolution. Lithos, doi:10.1016/ j.lithos.2007.05.005

Milord, I., E. W. Sawyer, and M. Brown. 2001. Formation of diatexite migmatite and granite magma during anatexis of semi-pelitic metasedimentary rocks: An example from St. Malo, France. Journal of Petrology 42:487-505

Morand, V. J. 1990. Low-pressure regional metamorphism in the Omeo Metamorphic Complex, Victoria, Australia. Journal of Metamorphic Geology 8:1-12.

Mortimer, N. 2004. Basement gabbro from the Lord Howe Rise. New Zealand Journal of Geology and Geophysics 47:501-507.

Mortimer, N., A. J. Tulloch, R. N. Spark, N. W. Walker, E. Ladley, A. Allibone, and D. L. Kimbrough. 1999a. Overview of the Median Batholith, New Zealand: A new interpretation of the geology of the Median Tectonic Zone and adjacent rocks. Journal of African Earth Sciences 29:257-268. 
Mortimer, N., B. Gans, A. Calvert, and N. W. Walker. 1999b. Geology and geochronometry of the east edge of the Median Batholith (Median Tectonic Zone): A new perspective on Permian to Cretaceous crustal growth of New Zealand. The Island Arc 8:404-425.

Mortimer, N., K. Hoernle, F. Hauff, J. M. Palin, W. J. Dunlap, R. Werner, and K. Faure. 2006. New constraints on the age and evolution of the Wishbone Ridge, southwest Pacific Cretaceous microplates, and Zealandia-West Antarctica breakup. Geology 3:185-188.

Muir, R., T. R. Ireland, S. D. Weaver, and J. D. Bradshaw. 1994. Ion microprobe $\mathrm{U}-\mathrm{Pb}$ zircon geochronology of granitic magmatism in the Western Province of the South Island, New Zealand. Chemical Geology 113:171-189.

Muir, R. J., S. D. Weaver, J. D. Bradshaw, G. N. Eby, and J. A. Evans. 1995. The Cretaceous Separation Point Batholith, New Zealand; granitoid magmas formed by melting of mafic lithosphere. Journal of Geological Society of London 152:689-701.

Muir, R. J., T. R. Ireland, S. D. Weaver, and J. D. Bradshaw. 1996. Ion microprobe dating of Paleozoic granitoids: Devonian magmatism in New Zealand and correlations with Australia and Antarctica. Chemical Geology 127:191-210.

Muir, R. J., T. R. Ireland, S. D. Weaver, J. D. Bradshaw, T. E. Waight, R. Jongens, and G. N. Eby. 1997. SHRIMP U-Pb geochronology of Cretaceous magmatism in northwest Nelson-Westland, South Island, New Zealand. New Zealand Journal of Geology and Geophysics 40:453-463.

Muir, R., T. R. Ireland, S. D. Weaver, J. D. Bradshaw, J. A. Evans, G. N. Eby, and D. Shelley. 1998. Geochronology and geochemistry of a Mesozoic magmatic arc system, Fiordland, New Zealand. Journal of the Geological Society of London 155:1037-1053.

Mukasa, S. B., and I. W. D. Dalziel. 2000. Marie Byrd Land, West Antarctica: Evolution of Gondwana's Pacific margin constrained by zircon $\mathrm{U}-\mathrm{Pb}$ geochronology and feldspar common- $\mathrm{Pb}$ isotopic compositions. Bulletin of the Geological Society of America 112:611-627.

Olsen, S. N., B. D. Marsh, and L. P. Baumgartner. 2005. Modelling midcrustal migmatite terrains as feeder zones for granite plutons: The competing dynamics of melt transfer by bulk versus porous flow. Transactions of the Royal Society of Edinburgh, Earth Sciences 95:49-58.

Pankhurst, R. J., S. D. Weaver, J. D. Bradshaw, B. C. Storey, and T. R. Ireland. 1998. Geochronology and geochemistry of pre-Jurassic superterranes in Marie Byrd Land, Antarctica. Journal of Geophysical Research 103:2529-2547.

Regenauer-Lieb, K., R. F. Wienberg, and G. Rosenbaum. 2006. The effects of energy feedbacks on continental strength. Nature 442:67-70.

Richard, S. M., C. H. Smith, D. K. Kimbrough, G. Fitzgerald, B. P. Luyendyk, and M. O. McWilliams. 1994. Cooling history of the northern Ford Ranges, Marie Byrd Land, West Antarctica. Tectonics 13:837-857.

Richards, S. W., and W. J. Collins. 2002. The Cooma Metamorphic Complex, a low-P, high-T (LPHT) regional aureole beneath the Murrumbidgee Batholith. Journal of Metamorphic Geology 20(1):119-134, doi:10.1046/j.0263-4929.2001.00360.x.

Ritzwoller, M. H., N. M. Shapiro, A. L. Levshin, and G. M. Leahy. 2001. Crustal and upper mantle structure beneath Antarctica and surrounding oceans. Journal of Geophysical Research B 106:30645-30670.

Rocchi, S., P. Armienti, and G. Di Vincenzo. 2005. No plume, no rift magmatism in the West Antarctic Rift. In Plates, Plumes, and Paradigms, eds. G. R. Foulger, J. Natland, D. Presnall and D. L. Anderson, Geological Society of America Special Paper 388:435-447.

Rossetti, F., G. DiVincenzo, A. L. Läufer, F. Lisker, S. Rocchi, and F. Storti. 2003a. Cenozoic right-lateral strike-slip faulting in North Victoria Land: An integrated structural, AFT and ${ }^{40} \mathrm{Ar}-{ }^{39} \mathrm{Ar}$ study. In 9 th International Symposium on Antarctic Earth Sciences-Antarctic Contributions to Global Earth Science, eds. D. K. Fütterer, D. Damaske, G. Kleinschmidt, H. Miller and F. Tessensohn, pp. 283-284. Potsdam: Terra Nostra.
Rossetti, F., F. Lisker, F. Storti, and A. L. Läufer. 2003b. Tectonic and denudational history of the Rennick Graben, North Victoria Land: Implications for the evolution of rifting between East and West Antarctica. Tectonics 22(2):1016, doi:10.1029/2002TC001416, 2003.

Rossetti, F., F. Tecce, L. Aldega, M. Brilli, and C. Faccenna. 2006. Deformation and fluid flow during orogeny at the palaeo-Pacific active margin of Gondwana: The Early Palaeozoic Robertson Bay accretionary complex (north Victoria Land, Antarctica). Journal of Metamorphic Geology 24:33-53.

Saito, S., F. Korhonen, M. Brown, and C. S. Siddoway. 2007. Petrogenesis of granites in the Fosdick migmatite dome, Marie Byrd Land, West Antarctica. In Antarctica: A Keystone in a Changing World-Online Proceedings for the Tenth International Symposium on Antarctic Earth Sciences, eds. Cooper, A. K., C. R. Raymond et al., USGS Open-File Report 2007-1047. Extended Abstract 105, http://pubs.usgs. gov/of/2007/1047/.

Salvini, F., G. Brancolini, M. Busetti, F. Storti, F. Mazzarini, and F. Coren. 1997. Cenozoic geodynamics of the Ross Sea region, Antarctica: Crustal extension, intraplate strike-slip faulting, and tectonic inheritance. Journal of Geophysical Research 102:24669-24696.

Sawyer, E. W. 1998. Formation and evolution of granite magmas during crustal reworking: The significance of diatexites. Journal of Petrology 39:1147-1167.

Sawyer, E. W. 2001. Melt segregation in the continental crust: Distribution and movement of melt in anatectic rocks. Journal of Metamorphic Geology 19:291-309.

Sawyer, E. W. 2004. Morphological variations in migmatites: importance of melt fraction and syn-migmatization strain. In Scientific Sessions: Abstracts (part 1), 32nd International Geological Congress, Florence, Italy, 2004, Abstract 86-9, p. 423.

Scott, J. M., and A. F. Cooper. 2006. Early Cretaceous extensional exhumation of the lower crust of a magmatic arc: Evidence from the Mount Irene Shear Zone, Fiordland, New Zealand. Tectonics 25, doi.10.1029/2005TC001890.

Siddoway, C. S., S. Baldwin, G. Fitzgerald, C. M. Fanning, and B. P. Luyendyk. 2004a. Ross Sea mylonites and the timing of intracontinental extension within the West Antarctic rift system. Geology 32:57-60.

Siddoway, C. S., S. M. Richard, C. M. Fanning, and B. P. Luyendyk. 2004b. Origin and emplacement of a middle Cretaceous gneiss dome, Fosdick Mountains, West Antarctica. In Gneiss Domes in Orogeny, eds. D. L. Whitney, C. Teyssier, and C. S. Siddoway, Geological Society of America Special Paper 380:267-294.

Siddoway, C. S., L. C. Sass III, and R. Esser. 2005. Kinematic history of Marie Byrd Land terrane, West Antarctica: Direct evidence from Cretaceous mafic dykes. In Terrane Processes at the Margin of Gondwana, eds. A. Vaughan, P. Leat and R. J. Pankhurst, Geological Society of London Special Publication 246:417-438.

Siddoway, C. S., C. M. Fanning, S. C. Kruckenberg, and S. C. Fadrhonc. 2006. U-Pb SHRIMP investigation of the timing and duration of melt production and migration in a Pacific margin gneiss dome, Fosdick Mountains, Antarctica. Eos Transactions of the American Geophysical Union, Fall Meeting Supplement 87, Abstract V23D-0661.

Sieminski, A., E. Debayle, and J. J. Leveque. 2003. Seismic evidence for deep low-velocity anomalies in the transition zone beneath West Antarctica. Earth and Planetary Science Letters 216:645-661.

Smith, C. H. 1992. Metapelitic migmatites at the granulite facies transition, Fosdick Mountains, Antarctica. In Recent Progress in Antarctic Earth Science, eds. Y. Yoshida, K. Kaminuma, and K. Shiraishi, pp. 295-301. Tokyo: Terra Publications.

Smith, C. H. 1996. Migmatites of the Alexandra Mountains, West Antarctica: Pressure-temperature conditions of formation and regional context. Geologisches Jahrbuch B 52:169-178.

Smith, C. H. 1997. Mid-crustal processes during Cretaceous rifting, Fosdick Mountains, Marie Byrd Land. In The Antarctic Region: Geological Evolution and Processes, ed. C. A. Ricci, pp. 313-320. Siena: Terra Antartica Publication. 
Sorlien, C. C., B. P. Luyendyk, D. S. Wilson, R. C. Decesari, L. R. Bartek, and J. B. Diebold. 2007. Oligocene development of the West Antarctic Ice Sheet recorded in eastern Ross Sea strata. Geology 35:467-470.

Spell, T. L., I. McDougall, and A. J. Tulloch. 2000. Thermochronological constraints on the breakup of the Pacific Gondwana margin: The Paparoa metamorphic core complex, South Island, New Zealand. Tectonics 19:433-451.

Squire, R. J., I. H. Campbell, C. M. Allen, and C. J. L. Wilson. 2006. Did the Transgondwanan Supermountain trigger the explosive radiation of animals on Earth? Earth and Planetary Science Letters 250:116-133.

Stern, T., and U. S. ten Brink. 1989. Flexural uplift of the Transantarctic mountains. Journal of Geophysical Research 94:10315-10330.

Stock, J. M., and S. C. Cande. 2002. Tectonic history of Antarctic seafloor in the Australia-New Zealand-South Pacific sector: Implications for Antarctic continental tectonics. In Antarctica at the Close of a Millennium, eds. J. A. Gamble, D. N. B. Skinner and S. Henry, pp. 251-259. Welllington: Royal Society of New Zealand.

Storey, B. C. 1991. The crustal blocks of West Antarctica within Gondwana: Reconstruction and break-up model. In Geological Evolution of Antarctica, eds. M. R. A. Thomson, J. A. Crame, and J. W. Thomson, pp. 587-592. Cambridge: Cambridge University Press.

Storey, B. C. 1992. Role of subduction-plate boundary forces during the initial stages of Gondwana break-up: Evidence from the proto-Pacific margin of Antarctica. In Magmatism and the Causes of Continental Breakup, eds. B. C. Storey, T. Alabaster, and R. J. Pankhurst, Geological Society Special Publication 68:165-184.

Storey, B., T. Leat, S. D. Weaver, R. J. Pankhurst, J. D. Bradshaw, and S. Kelley. 1999. Mantle plumes and Antarctica-New Zealand rifting: Evidence from mid-Cretaceous mafic dykes. Journal of the Geological Society of London 156:659-671.

Stump, E. 1995. The Ross Orogen of the Transantarctic Mountains: New York: Cambridge University Press.

Sutherland, R. 1999. Basement geology and tectonic development of the greater New Zealand region: An interpretation from regional magnetic data. Tectonophysics 308:341-362.

Sutherland, R., and C. Hollis. 2001. Cretaceous demise of the Moa plate and strike-slip motion at the Gondwana margin. Geology 29:279-282.

Taylor, B. 2006. The single largest oceanic plateau: Ontong Java-ManihikiHikurangi. Earth and Planetary Science Letters 241:372-380.

ten Brink, U. S., R. I. Hackney, S. Bannister, T. A. Stern, and Y. Makovsky. 1997. Uplift of the Transantarctic Mountains and the bedrock beneath the East Antarctic ice sheet. Journal of Geophysical Research, Solid Earth 102:27603-27621.

Tessensohn, F., and G. Wörner. 1991. The Ross Sea Rift System: Structure, evolution and analogues. In Geological Evolution of Antarctica, eds. M. R. A. Thomson, J. A. Crame, and J. W. Thomson., pp. 273-277. Cambridge: Cambridge University Press.

Teyssier, C., and D. L. Whitney. 2002. Gneiss domes and orogeny. Geology 30:1139-1142.

Teyssier, C., E. Ferré, D. L. Whitney, B. Norlander, O. Vanderhaeghe, and D. Parkinson. 2005. Flow of partially molten crust and origin of detachments during collapse of the Cordilleran orogen. In High-Strain Zones: Structure and Physical Properties, eds. D. Bruhn and L. Burlini. Geological Society of London Special Publication 245:39-64.

Thompson, A. B. 1996. Fertility of crustal rocks during anatexis. Transactions of the Royal Society of Edinburgh 87:1-10.

Tikoff, B., C. Teyssier, and C. Waters. 2002. Clutch tectonics and the partial attachment of lithospheric layers. EGU Stephan Mueller Special Publication Series 1:57-73.

Trey, H., J. Makris, G. Brancolini, and A. K. Cooper. 1997. The Eastern Basin Crustal model from wide-angle reflection data, Ross Sea, Antarctica Structure of the Southern Central Trough, Western Ross Sea. In The Antarctic Region: Geological Evolution and Processes, ed. C. A. Ricci, pp. 643-648. Siena: Terra Antartica Publication.
Trey, H., A. K. Cooper, G. Pellis, B. della Vedova, G. Cochrane, G. Brancolini, and J. Makris. 1999. Transect across the West Antarctic rift system in the Ross Sea, Antarctica. Tectonophysics 301:61-74.

Tulloch, A. J., and D. L. Kimbrough. 1989. The Paparoa metamorphic core complex, New Zealand: Cretaceous extension associated with fragmentation of the Pacific margin of Gondwana. Tectonics 8:1217-1234.

Tulloch, A. J., and D. L. Kimbrough. 2003. Paired plutonic belts in convergent margins and the development of high $\mathrm{Na}, \mathrm{Al}, \mathrm{Sr}$, low Y magmatism: The Peninsular Ranges Batholith of California and the Median Batholith of New Zealand. Geological Society of America Special Publication 374:275-295.

Tulloch, A. J., D. Kimbrough, D., and R. Wood. 1991. Carboniferous granite basement dredged from a site on the southwest margin of the Challenger Plateau. New Zealand Journal of Geology and Geophysics $34: 121-126$

Vaughan, A. M., and R. A. Livermore. 2005. Episodicity of Mesozoic terrane accretion along the Pacific margin of Gondwana: Implications for superplume-plate interactions. In Terrane Processes at the Margin of Gondwana, eds. A. Vaughan, P. Leat and R. J. Pankhurst, Geological Society of London Special Publication 246:143-178.

Vaughan, A. M., and B. C. Storey. 2000. The eastern Palmer Land shear zone: A new terrane accretion model for the Mesozoic development of the Antarctic Peninsula. Journal of the Geological Society of London 157:1243-1256.

Vaughan, A. M., S. P. Kelley, and B. C. Storey. 2002a. Age of ductile deformation on the Eastern Palmer Land Shear Zone, Antarctica, and implications for timing of Mesozoic terrane collision. Geological Magazine 139:465-471.

Vaughan, A. M., R. J. Pankhurst, and C. M. Fanning. 2002b. A midCretaceous age for the Palmer Land event, Antarctic Peninsula: Implications for terrane accretion timing and Gondwana palaeolatitudes. Journal of the Geological Society of London 159:113-116.

Vaughan, D. G., F. Ferraccioli, N. Frearson, H. F. J. Corr, A. O'Hare, D. Mach, J. W. Holt, D. D. Blankenship, D. L. Morse, and D. A. Young. 2006. New boundary conditions for the West Antarctic Ice Sheet: Subglacial topography beneath Pine Island Glacier. Geophysical Research Letters 33:L09501, doi:10.1029/2005GL025588.

Vernon, R. H., and S. E. Johnson. 2000. Transition from gneiss to migmatite and the relationship of leucosome to peraluminous granodiorite in the Cooma Complex, SE Australia. Journal of the Virtual Explorer 2. http://virtualexplorer.com.au/special/meansvolume/contribs/vernon/ index.html.

Wandres, A. M., and J. D. Bradshaw. 2005. New Zealand tectonostratigraphy and implications from conglomeratic rocks for the configuration of the SW Pacific margin of Gondwana. In Terrane Processes at the Margin of Gondwana, eds. A. Vaughan, P. Leat and R. J. Pankhurst, Geological Society of London Special Publication 246:179-216.

Weaver, S. D., J. D. Bradshaw, and C. J. Adams. 1991. Granitoids of the Ford Ranges, Marie Byrd Land, Antarctica. In Geological Evolution of Antarctica, eds. M. R. A. Thomson, J. A. Crame, and J. W. Thomson, pp. 345-351. Cambridge: Cambridge University Press.

Weaver, S. D., C. J. Adams, R. J. Pankhurst, and I. L. Gibson. 1992. Granites of Edward VII Peninsula, Marie Byrd Land: Anorogenic magmatism related to Antarctic-New Zealand rifting. In Proceedings of the Second Hutton Symposium on the Origin of Granites and Related Rocks, eds. E. Brown and B. W. Chappell. Transactions of the Royal Society of Edinburgh, Earth Sciences 83:281-290.

Weaver, S. D., B. C. Storey, R. J. Pankhurst, S. B. Mukasa, V. Divenere, and J. D. Bradshaw. 1994. Antarctic-New Zealand rifting and Marie Byrd Land lithospheric magmatism linked to ridge subduction and mantle plume activity. Geology 22:811-814.

Weaver, S. D., R. J. Pankhurst, B. C. Storey, J. D. Bradshaw, and R. Muir. 1995. Cretaceous magmatism along the SW Pacific Gondwana margin. In Abstracts-VII International Symposium on Antarctic Earth Sciences, ed. C. A. Ricci, p. 402. Siena: Terra Antartica Publication. 
Weinberg, R. F. 2006. Melt segregation structures in granitic plutons. Geology 34:305-308.

Wilbanks, J. R. 1972. Geology of the Fosdick Mountains, Marie Byrd Land. In Antarctic Geology and Geophysics, ed. R. J. Adie, pp. 277-284. Oslo: Universitetsforlaget.

Wilson, D., and B. P. Luyendyk. 2006. Bedrock platforms within the Ross Embayment, West Antarctica: Hypotheses for ice sheet history, wave erosion, Cenozoic extension, and thermal subsidence. Geochemistry Geophysics Geosystems 7(2):Q12011, doi:10.1029/2006GC001294.

Wilson, G. S., A. P. Roberts, K. L. Verosub, F. Florindo, and L. Sagnotti. 1998. Magnetobiostratigraphic chronology of the Eocene-Oligocene transition in the CIROS-1 core, Victoria Land margin, Antarctica; implications for Antarctic glacial history. Bulletin of the Geological Society of America 110:35-47.
Wilson, T. J. 1992. Mesozoic and Cenozoic kinematic evolution of the Transantarctic Mountains. In Recent Progress in Antarctic Earth Science, eds. Y. Yoshida, K. Kaminuma, and K. Shiraishi, pp. 303-314. Tokyo: Terra Scientific Publishing.

Wilson, T. J. 1993. Jurassic faulting and magmatism in the Transantarctic Mountains; implications for Gondwana breakup. In Assembly, Evolution and Dispersal: Proceedings of the Gondwana Eight Symposium, eds. R. H. Findlay, R. Unrug, M. R. Banks and J. J. Veevers, pp. 563-572. Hobart, Tasmania: International Gondwana Symposium.

Winberry, J. P., and S. Anandakrishnan. 2004. Crustal structure of the West Antarctic rift system and Marie Byrd Land hotspot. Geology 32:977-980. 